\title{
Translating satisfaction determination from health care to the automotive industry
}

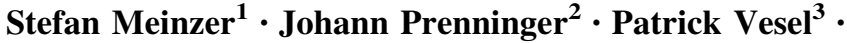 \\ Johannes Kornhuber ${ }^{4} \cdot$ Judith $_{\text {Volmer }}^{5} \cdot$ Joachim Hornegger $^{6}$ • \\ Björn M. Eskofier ${ }^{1}$
}

\begin{abstract}
This study is based on the case of BMW, and aims to improve the determination of perceived consumer satisfaction in the automotive industry by transferring existing knowledge from the health care sector. A literature analysis of the health care sector and the automotive industry was conducted to identify the common concepts of determining satisfaction. These were the service encounter, situational factors, and sociodemographics. The practical application was tested by analyzing a contemporary survey from BMW. Based on the findings, managers responsible for customer satisfaction in after-sales services in the automotive industry could improve measurement of customer satisfaction.
\end{abstract}

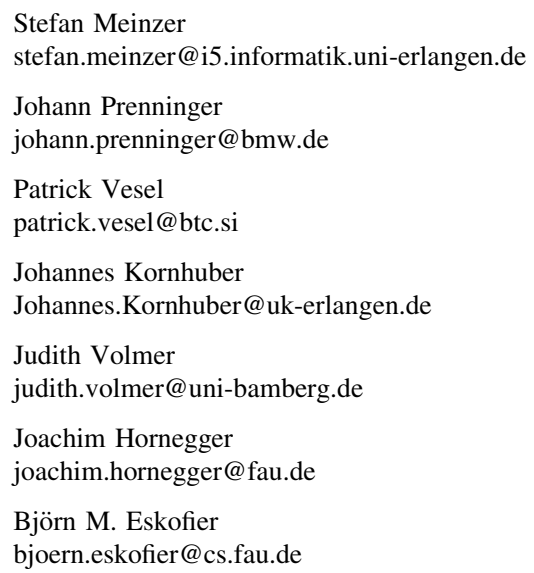

1 Digital Sports Group, Pattern Recognition Lab, Department of Computer Science, FriedrichAlexander-University Erlangen-Nürnberg, Haberstr. 2, 91058 Erlangen, Germany

2 Field Data Analytics, BMW Group Munich, Lilienthalallee 32, 80788 Munich, Germany

3 Marketing Research and Development, BTC d.d., Smartinska 152, 1000 Ljubljana, Slovenia 
Keywords Customer satisfaction - Patient satisfaction - Automotive industry . Health care $\cdot$ BMW

\section{Introduction}

The time when success in a service industry was defined only by products and services is already history. Good products and services are no longer sufficient to survive in a tough competitive environment. Companies must now define themselves by consumer expectations (Dünzl and Kirylak 1997; Rao et al. 2006; Sivakumar et al. 2014; Yarris et al. 2012). In health care, a solid knowledge of patients' expectations, such as the information they want to receive and how, is the fundamental driver to satisfy patients even in critical situations (Leydon et al. 2000; Makarem and Al-Amin 2014). Transferring this phenomenon to service industries, the question arises: would applying the mechanisms for determining patient satisfaction help to improve customer satisfaction in, for example, the automotive industry? We ask how knowledge transfer could help to satisfy customers who experience service failures such as a repeat repair (Meinzer et al. 2010) and in general what and how the automotive industry can learn from the health care sector by transferring existing knowledge to new instances, problems, and domains. There is a high focus on personalized consumer treatment in health care (Blanchard et al. 1990; Laith and Feras 2011; Sun et al. 2000; Yarris et al. 2012) not least because of the potential consequences that can arise as a result of treatment. The knowledge of patients' expectations arises from well-defined questionnaires that help the health care sector to identify the most important satisfaction drivers and patient expectations. However, individual treatment is a key component to securing competitive advantage in every service-oriented business (Blocker et al. 2011; Zeithaml 1988). Using the metaphor of Hudak et al. (2003), treating patients as customers allows the transfer of insights into the determination of perceived satisfaction from the health care sector to the automotive industry. For example, transferring best practices from retailers to the health care sector has been done before (Blanchard et al. 2008). Cross-industrial translations of customer satisfaction and service quality models have made valuable contributions to the literature (Corbin et al. 2001). Corbin et al. (2001) compares service processes from the health care sector with other service industries such as Wal-Mart or McDonald's. They argue that every service process and customer treatment, such as patient-physician or customer-provider relationships, need to follow certain principles to create and secure customer satisfaction. According to Corbin et al. (2001), a cross-industrial

\footnotetext{
4 Department of Psychiatry and Psychotherapy, Friedrich-Alexander-University Erlangen-Nürnberg, Schwabachanlage 6, 91054 Erlangen, Germany

5 Department of Psychology, Work and Organizational Psychology Group, Otto-FriedrichUniversity Bamberg, An der Weberei 5, 96047 Bamberg, Germany

6 Pattern Recognition Lab, Department of Computer Science, Friedrich-Alexander-University Erlangen-Nürnberg, Martensstr. 3, 91058 Erlangen, Germany
} 
knowledge transfer is possible for intangible goods as defined by Shostack (1977), such as service processes. Services are always related to customer treatment and, independent of the service industry, can only be evaluated after consumption (Bouman and Van der Wiele 1992; Corbin et al. 2001; Parasuraman et al. 1985), for example, using questionnaires. A patient with a health issue needs to be treated in the medical health care environment and consequently becomes a health care service customer (Hudak et al. 2003). In the automotive industry, a customer needs a service treatment such as a maintenance or repair visit (Bloemer and Lemmink 1992; Müller 1991; Tukker 2004). To make comparisons of these sectors meaningful, the car buying process, which is characterized as a highly tangible good because of the car as a product, has to be excluded for a greater focus on the intangible aspects of service processes in terms of car repair or maintenance. Intangible goods are given greater attention from a management perspective to increase the competitive advantage of their business (Stryja et al. 2015) and are the focus of this paper. They are used as the common construct for our cross-industrial comparisons. Similar approaches have been performed in the health care and retail sectors as shown above. A lack of research on service enhancement has already been identified in manufacturing industries, such as the car industry (Gebauer et al. 2008). Despite our best efforts, the existing research or established approaches for a cross-industrial translation from the health care sector to the automotive industry could not be examined in this literature review. We will close this gap by showing how to improve the determination of perceived satisfaction in the automotive industry using a questionnaire to show knowledge transfer from the health care sector based on the common denominator of intangible goods. We examine how to improve the determination of service satisfaction based on health care findings. The fundamental role of consumer treatment is well known in the health care sector (Hare et al. 2013), but has also been examined as a key concept to strengthen service businesses and secure competitive advantages, especially in the after-sales environment (Gebauer et al. 2008). After-sales services in the US industries generate an estimated revenue of 6-8 billion dollars annually (Gaiardelli et al. 2007) and generally after-sales service profit is higher than sales profit (ADL 2015). Consequently, the focus on implications for the after-sales services as intangible goods in the automotive industry based on findings from the health care sector in this work is considered as a new contribution to the existing research. Therefore, we follow the definition of treating patients as customers as described by Hudak et al. (2003). The main differentiation between the two sectors is the customers' independence in service selection. This independency is limited, especially in critical medical health care situations; therefore, the definition of patients as being customers is also limited. However, comparable service relationship constructs are present in this scenario, such as the customers' participation in a service (Bettencourt 1997). The better the interaction between service industries and its customers, the better the perceived experience and consequently the perceived satisfaction. This argument does not address situations where patients are no longer able to participate in the service relationship because of their poor medical conditions. Overall, the cross-industrial comparison of the health care and automotive industries is possible at a meta level for the customer treatment as an 
intangible good. Comparable constructs such as service encounters or failures (such as waiting time) are equally relevant for all service industries to secure competitive advantages in satisfaction and loyalty (Chuang et al. 2012; Corbin et al. 2001; Reichheld and Sasser 1990; Sivakumar et al. 2014).

Taking the premium car manufacturer BMW as a representative example, the J.D. Power Survey results from 2013 and 2014 showed an increase in the Customer Service Index, but the company remains behind the luxury brand average (J.D. Powers 2013, 2014). BMW, however, is still the most valuable brand in the automotive industry, based on the Forbes ranking from November 2013 (Forbes 2013). We will examine how to improve determination of service satisfaction based on findings from health care. By identifying the most important determinants, based on an empirical analysis, we aim to improve understanding of customer expectations of a dealer service and hence to increase their satisfaction with BMW. BMW has a high focus on customer satisfaction, as the chairman of the board, Dr. Reithofer, has made clear (BMW 2014).

Our goal was to prove that the determination of perceived customer satisfaction in health care and the automotive industry is closely related. Currently, the importance of perceptions in the two sectors and the concepts to capture them are separately researched. Examining the similarities between the concepts for perceived satisfaction determination, our study will show the implications for the automotive industry that can be derived from the health care sector. This novel approach is proven by the case of the premium car manufacturer BMW.

The first section provides a theoretical background that shows the role and measurement of perceived satisfaction in service industries. The second part explains the conceptual framework, and sets out the most important concepts for the determination of perceived satisfaction in health care and the automotive industry, together with a literature review. To prove the findings from the literature empirically, Sect. 3 shows the results of a customer satisfaction survey from BMW. After summarizing the results, the paper explains the management implications of the new concepts for the automotive industry, and specifically for BMW. The paper closes with some limitations and ideas for further research.

\section{Theoretical background}

\subsection{The role of satisfaction in general and for management}

Customer satisfaction can be seen as one of the most important pieces of information for management decisions. Repeat purchase, brand loyalty, and willingness to pay are significantly affected by customer satisfaction (Churchill and Surprenant 1982). It is, therefore, a very important construct, which receives considerable management attention (Mittal and Frennea 2010).

Customer satisfaction plays an important role in establishing successful longterm customer relationships (Chojnacki 2000; Homburg and Rudolph 2001). Even if there is no common understanding of the exact relationship between satisfaction and loyalty, there is no doubt about its existence (Bennett and Rundle-Thiele 2004; 
Blocker et al. 2011; Dong et al. 2011; Flint et al. 2011; Homburg and Giering 2001). Jones and Suh (2000) identified overall satisfaction to be the main predictor of loyalty. However, satisfaction does not linearly result in loyalty, which is why it is necessary to differentiate between these constructs (Kumar et al. 2013; Mittal and Lassar 1998).

Herrmann et al. (2000) found that customer price elasticity could be optimized as a result of customer satisfaction, resulting in a greater willingness to pay for products and services. Customer satisfaction also often leads to positive word-ofmouth recommendations to other consumers as a positive side effect (Mangold et al. 1999; Reichheld and Sasser 1990). Because such recommendations increase revenue, this aspect has high managerial relevance. The general impact of customer satisfaction on profitability and share-of-wallet has been proven by several studies, including Anderson et al. (2004) and Cooil et al. (2007). The Return on invest of a company is described as a function of customer satisfaction, strongly based on previous customer experiences (Anderson et al. 1994).

To maintain high customer satisfaction and thus create customer value, consumer orientation is identified as the most important management target (Blocker et al. 2011; Zeithaml 1988). Highly consumer-oriented processes were shown by Sun et al. (2000) to be main predictors of satisfaction. High customer understanding and knowledge of the key drivers of satisfaction are therefore important. Effective customer satisfaction measurement is vital to reach the desired outcomes mentioned at the beginning of this section.

\subsection{The measurement of customer satisfaction and the importance of perceptions}

The measurement and interpretation of perceived consumer satisfaction has long been an important field of research in the service industries (Anderson and Sullivan 1993; Herrmann et al. 2000; Homburg and Rudolph 2001; Huang and Dubinsky 2013; Mittal and Lassar 1998; Yarris et al. 2012). Perceived customer satisfaction expresses how well the services provided by companies meet customer needs (Anderson and Sullivan 1993). If services do not fulfill customers' expectation (disconfirmation), consumers may be dissatisfied (Anderson 1973). Consequently, expectations need to be fulfilled or exceeded to achieve the customer's confirmation and secure satisfaction (Anderson and Sullivan 1993). The relationship between customer satisfaction and expectations is known as the confirmation/disconfirmation paradigm (Anderson 1973; Anderson and Sullivan 1993; Churchill and Surprenant 1982; Oliver 1980). The importance of capturing the perceived performance is consequently highly relevant to measure satisfaction (Cheng and Yang 2013; Johnson and Fornell 1991) and is uncontroversial across different services and industries (Herrmann et al. 2000; Homburg and Rudolph 2001; Huang and Dubinsky 2013; Mittal et al. 1998; Rao et al. 2006; Rhee and Bird 1996; Trout et al. 2000; Yarris et al. 2012). Companies define a detailed understanding of customer needs as an essential factor in their competitive strategies (Anderson and Sullivan 1993; Herrmann et al. 2000). The consideration of service quality as one of the most 
important antecedents of customer satisfaction helps service industries to establish a professional understanding of potential customer satisfaction drivers (Oh 1999).

Customer satisfaction and service quality are highly connected; therefore, it is helpful to define this connection. Three theoretical conclusions are discussed in the literature (Grönroos 1984, 2001; Hennig-Thurau and Klee 1997): that service quality and customer satisfaction are one and the same, that customer satisfaction is an antecedent of service quality or that service quality is an antecedent of customer satisfaction. The last approach is most popular (Caruana 2002; Cronin and Taylor 1992; Cronin et al. 2000; Grönroos 2001; Lee et al. 2000a, b; Wei et al. 2005; Xu et al. 2007) and the perspective taken in this study. However, a detailed understanding of the critical components of service quality is important for organizations to increase customers' perceived satisfaction (Seth et al. 2005) and their profitability (Zeithaml 2000). One of the most popular ways to measure service quality is by using the SERVQUAL scale (Parasuraman et al. 1988, 1991), which is widely used, including in recent studies (Jemmasi et al. 2011; Lee et al. 2000a) and the SERVPERF scale (Cronin and Taylor 1992). These two measurement scales can be seen as generic instruments (Randheer and AL-Motawa 2011; Rocha et al. 2013) to measure service quality as an antecedent for consumer satisfaction. In a review of various models, Seth et al. (2005) found 19 different approaches, which shows that various industries need to adapt service quality measurements, such as the retail industry (Sweeney et al. 1997; Teas 1993), hospitality sector (Mattsson 1992; Oh 1999), higher education (Spreng and Mackoy 1996), transportation industry (Frost and Kumar 2000), or the banking sector (Seth et al. 2005; Soteriou and Stavrinides 2000).

Comparable generic measurement batteries can be found for the determination of customer satisfaction. The most popular cross-industrial models are the American and European Customer Satisfaction Indices (CSI) defined by Gilbert and Veloutsou (2006), which comprise consumer expectations, perceived quality, and perceived value (Fornell et al. 1996). The CSI model is generally applicable to various sectors of the service industries and is produced annually to benchmark the considered companies. However, this cross-industrial assessment model is limited because the models need to be specified to continuously monitor processes and identify drivers for improvements in specific industrial sectors (Gilbert and Veloutsou 2006). For example, Deng et al. (2013) applied the American CSI to the hospitality sector by integrating consumption emotions, which resulted in the Hotel CSI. In addition, Hsu (2008) developed the e-CSI model for the online customer satisfaction determination and Kristensen et al. (2000) applied the European CSI to the Denmark Post by combining the generic measures with specific determinants from the post sector. A way to measure service features is the Customer Satisfaction Survey, which is related to transaction-specific service satisfaction (Gilbert et al. 1997). Service quality and various technical and functional service satisfaction measures are determined by this approach. Measuring the perceived quality of the complete consumption process is the scope of the Customer Satisfaction Barometer (CSB) based on Fornell (1992) and Hackl et al. (1996). Johnson and Fornell (1991) used the CSB as a standardized measurement battery for the general customer satisfaction, the perceived confirmation of customers' expectations, and the distance 
to the ideal consumption result from the customers' perspective. Generally, crossindustrial customer satisfaction is defined as a function of pre-purchase expectations and post-purchase perceived performance.

Specifically for the health care sector, the most popular and standardized satisfaction and quality measurement approach is related to the Hospital Consumer Assessment of Healthcare Providers and Systems, which was established by the Centers for Medicare and Medicaid Services in 2008 (Giordano et al. 2009; Makarem and Al-Amin 2014; Rothman et al. 2008). A survey consisting of 16 questions assessing specific perceived aspects of care was established (Darby et al. 2005). These hospital ratings are public and accessible by the patients. However, the causes for satisfaction in the health care sector need to be analyzed in detail and specific cultural and demographical conditions need to be determined (Raposo et al. 2009). Therefore, specific questionnaires were developed to capture the relevant process information perceived by the patients. Exemplary surveys to measure perceived satisfaction in the health care sector can be found in the literature (Boudreaux et al. 2000; Jackson et al. 2001; Sun et al. 2000; Oliver 1980; Raposo et al. 2009; Westbrook et al. 1982).

\section{Conceptual framework}

To generate a thorough understanding of the effective determination of perceived consumer satisfaction, we examined the most important concepts and corresponding determinants in the automotive industry and the health care sector.

\subsection{Concepts of customer satisfaction in service industries}

\subsubsection{The service encounter}

The service encounter is considered the basis for building customer satisfaction (Gil et al. 2008), because this concept is one of the most important antecedents in customer evaluation of service performance (Brown and Swartz 1989; Parasuraman et al. 1985). Historically, service encounters were considered as a dyadic process of customer interactions (Solomon et al. 1985; Surprenant and Solomon 1987). The construct was defined as the way the service provider interacted with the customer, for example, in a face-to-face communication. Perceived personal interaction is most often studied in service encounters (Gil et al. 2008; Meuter et al. 2000) and especially as an antecedent of customer satisfaction (Bitner et al. 1990; Gil et al. 2008). Customized communication often helps to enhance the customers' relationship with service providers (Boulding et al. 2005). It is important to understand customers' expectations to optimize personalized information transfer (Ford 2001). From the customers' perspective, the basic event is the moment when they interact with a service provider (Bitner et al. 1994). Relational benefits result from customer-provider interactions, such as time savings due to the communication of waiting times (Gwinner et al. 1998; Reynolds and Beatty 1999). To capture personal 
interaction during service encounters, it is important that both directions of communication between staff and consumers are recorded.

Beside personal interactions, service encounters also involve perceived processes and service characteristics (Bitner et al. 1997; Shostack 1985). It is the total workflow that defines customers' perception about the quality of service encounters and thus their satisfaction (Wynstra et al. 2006). A well-established customer interaction strategy has been identified as fundamentally important (Lindgreen et al. 2006). Personal customer interactions not only refers to service providers' interactions, but also to their delivery of services and goods (Brown and Gulycz 2006; Lindgreen et al. 2006). Therefore, for service encounters, we focus on personal interactions and perceived service characteristics.

\subsubsection{Situational factors}

Beside the service encounter itself, external factors may also influence perceived consumer satisfaction (Bagozzi 1978; Dabholkar and Bagozzi 2002; Lau and Ng 2001). These determinants may be defined by external influences, process-related circumstances in a service organization, or environmental conditions, and are described as situational factors. "Waiting time" or "perceived crowding" (for example, busy receptions in hospitals) are examples of these factors (Dong et al. 2008; Hui and Tse 1996; Nie 2000; Pruyn and Smidts 1998), which are described as being frustrating, stressful, and expensive when related to costs (van Dun et al. 2010). Underlying situations, such as "time pressure," significantly influence the individual perception (Blackwell et al. 1999; Hennig-Thurau and Klee 1997; Ravald and Grönroos 1996). Services that are perceived as convenient are likely to result in a higher degree of consumer loyalty and satisfaction (Blackwell et al. 1999). For specific consumer goods, situational factors also affect brand selection and impact. Some facility-specific determinants are also related to situational factors like the "location of a store" (Hennig-Thurau 2004). Lau and Ng (2001) examined the importance of the "proximity of others" as a significant factor that should be considered by service industries because consumers are more likely to talk about negative experiences, which may therefore affect reputation and satisfaction (Lau and $\mathrm{Ng}$ 2001; Mangold et al. 1999). There is a common understanding that inconvenient factors such as crowding or social anxiety decrease perceived service quality and thus consumer satisfaction (Dabholkar and Bagozzi 2002; Hui and Bateson 1991; Keaveney and Parthasarathy 2001; Maher et al. 1997). The internal climate of the organization may also affect consumers' perception (Yagil 2002), as can the "availability of goods" (Bloemer and Pauwels 1998).

\subsubsection{Sociodemographics}

In most studies, sociodemographic information was captured as a relevant indicator (Darley et al. 2008; Walker et al. 2003), with determinants such as age, sex, domicile, marital status, race, education level, and level of income. The determination of sociodemographics is considered particularly important for customer relationship models (Verhoef et al. 2003). 
Currently, there is no common understanding about the relationship between the sociodemographic data and satisfaction. Some authors have shown that there is no significant correlation between sociodemographics and satisfaction (Boudreaux et al. 2000; Bursch et al. 1993; Hall and Press 1996). Others observed clear dependencies (Baker and Cameron 1996; Jha et al. 2008; Sun et al. 2000). A moderating effect of income on satisfaction and on the share-of-wallet was identified by Cooil et al. (2007). Homburg and Giering (2001) examined personal characteristics and found income, age, and variety seeking to be strongly influential factors of the satisfaction-loyalty construct. Customers have to be individually treated according to their age because satisfaction in younger people is highly influenced by service encounters, whereas older people's satisfaction is also based on previous experience. The role of education is important, because better educated consumers ask for more information to make their decisions, which is reflected in perceived satisfaction (Cooil et al. 2007; Keaveney and Parthasarathy 2001). Furthermore, the relationship between income and product satisfaction was identified as being weaker for people with high incomes than for those with low incomes (Homburg and Giering 2001).

\subsection{Literature review of the customer satisfaction determinants in the automotive industry}

Keaveney (1995) found that the two dimensions of service encounters, personal interactions and perceived service characteristics, are significantly important for the automotive industry. Brito et al. (2007) and Yieh et al. (2007) focused on the importance of customer interaction, defined as information transfer to the customer, and the reverse direction of information transfer was examined by Bloemer and Lemmink (1992). The most prominent determinants for personal interactions within service encounters were information about administrative issues such as waiting time or forthcoming steps (Bloemer and Lemmink 1992; Yieh et al. 2007) and the explanation of results and charges (Bei and Chiao 2001; Brito et al. 2007). With respect to the personal interaction between customers and service personnel, honesty and integrity were prominent in our literature review (Devaraj et al. 2001; Hünecke and Gunkel 2012; Yieh et al. 2007). Customer satisfaction with staff skills was the most significant determinant in perceived service characteristics (Brito et al. 2007).

Situational factors were examined as the second fundamental concept of perceived consumer satisfaction. The most important determinants are time-related factors, such as perceived waiting time or the length of stay (Devaraj et al. 2001; Müller 1991). Related factors include whether the car is ready at the promised time (Devaraj et al. 2001) and the ease of getting an appointment. Furthermore, the time to first contact has also been identified as a relevant factor (Yieh et al. 2007). The total time for servicing a car or for a repair was identified as being significant by Biehal (1983) and Müller (1991). The ability to do the repair correctly at the first service encounter is identified as being an important predictor of consumer 


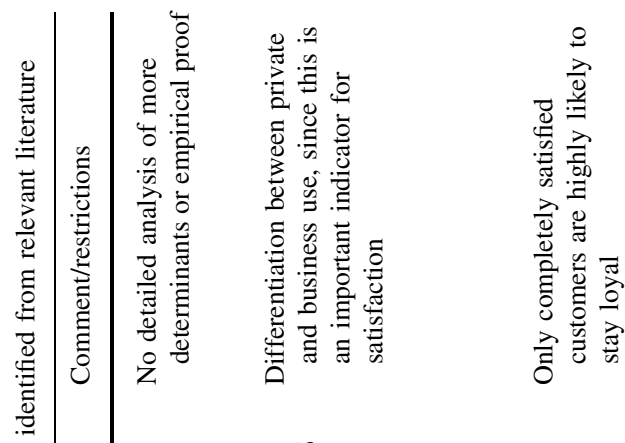

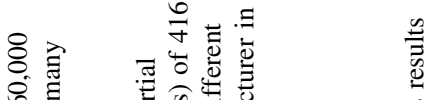

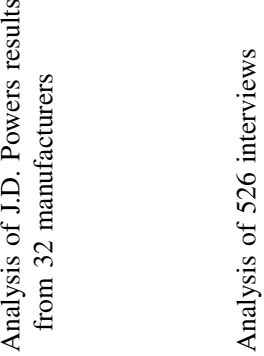

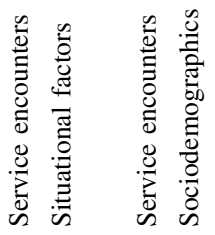
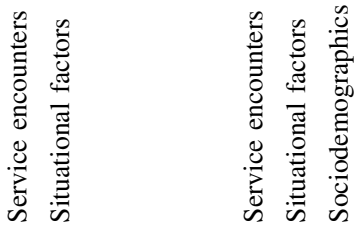

๖

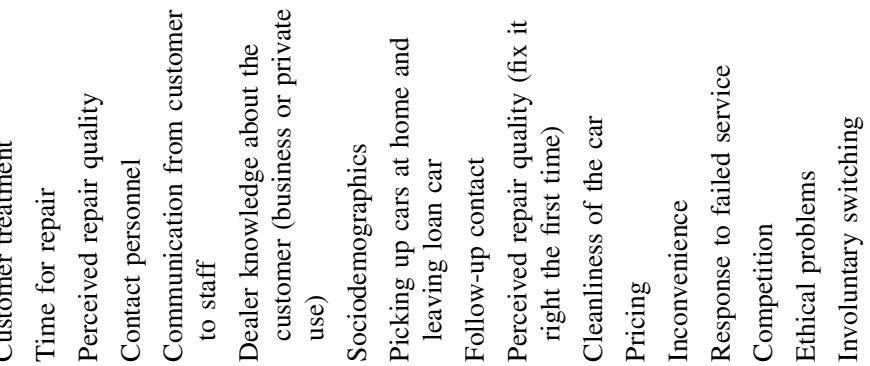

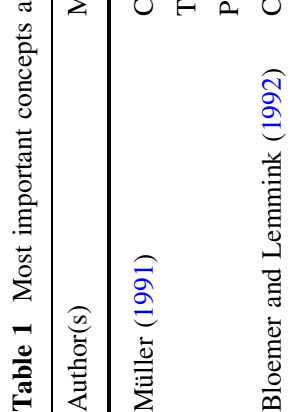

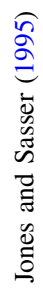

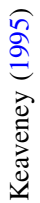




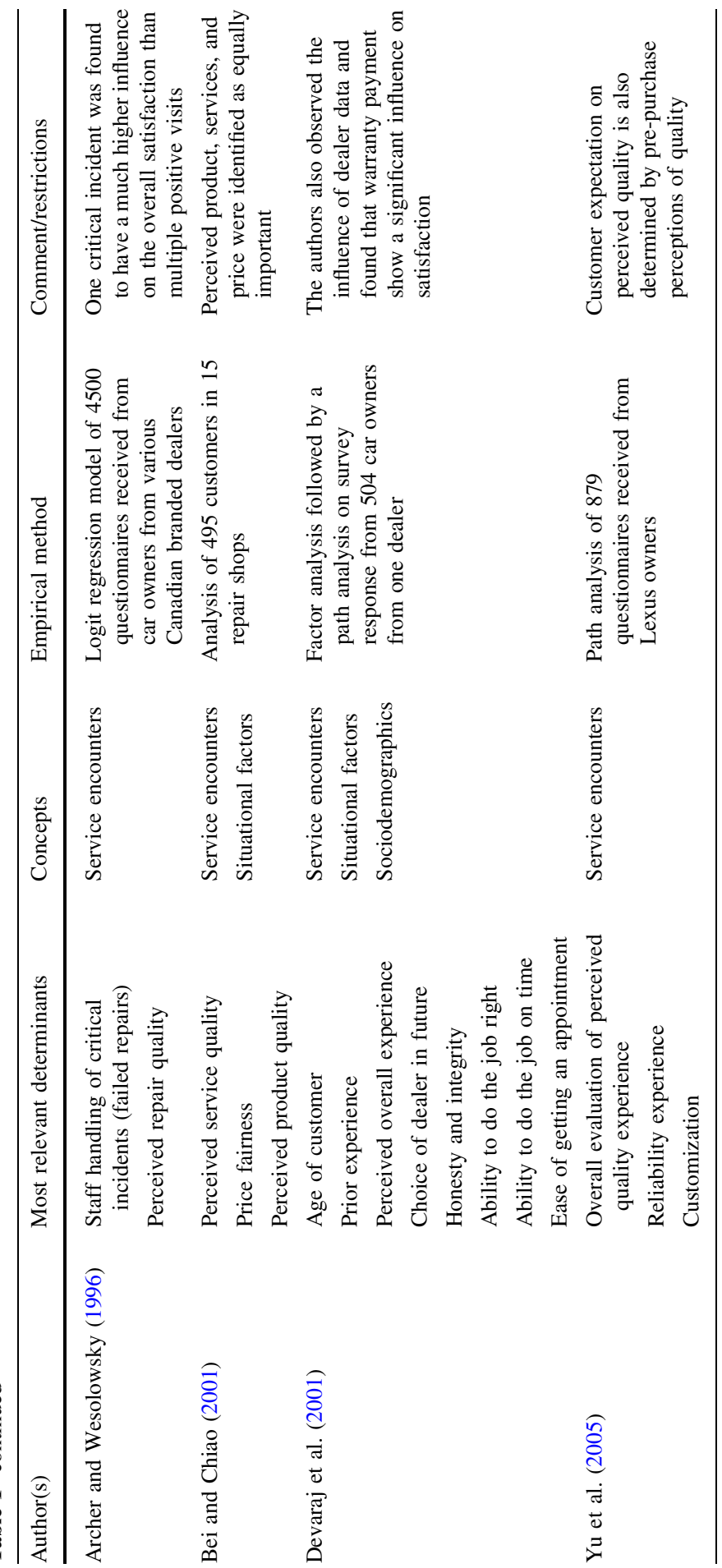




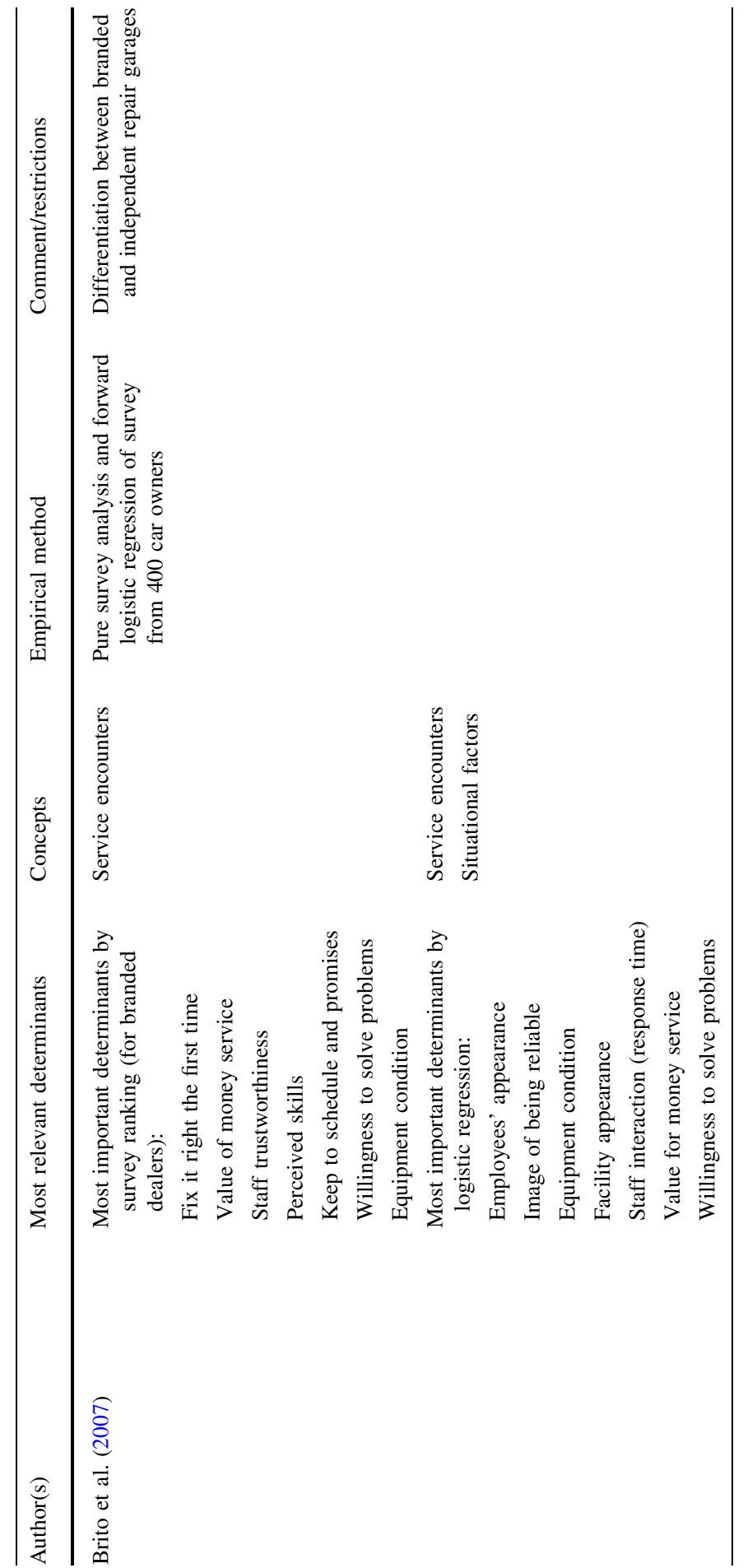




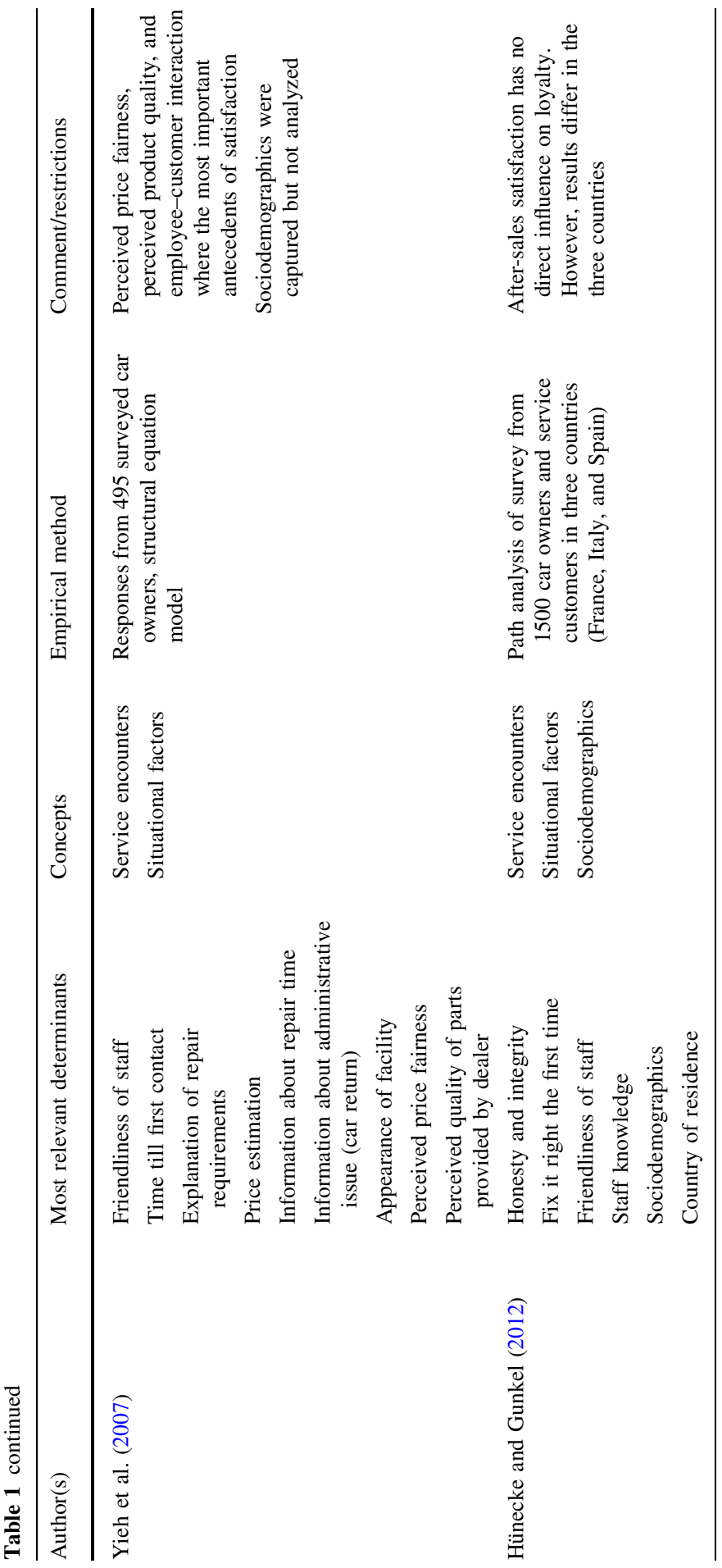




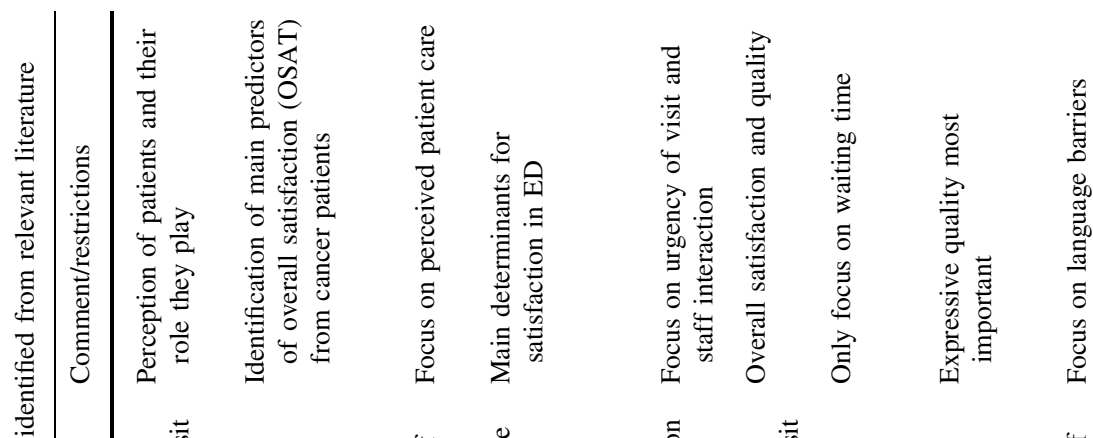

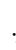

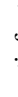

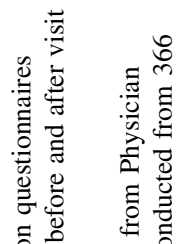

पั

.0ี 竞

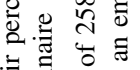

昰言

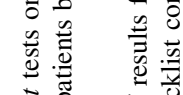

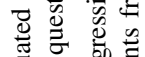

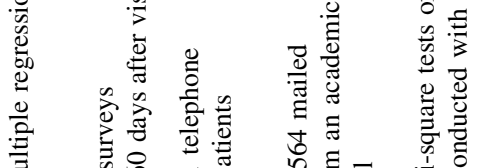

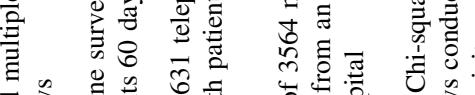

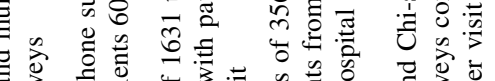

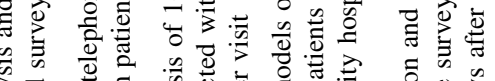

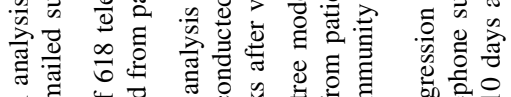

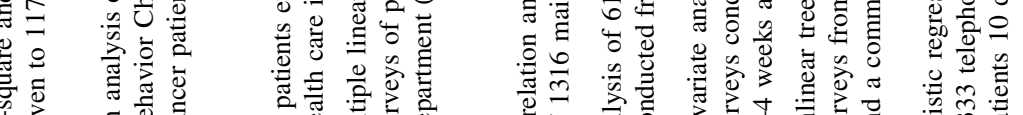

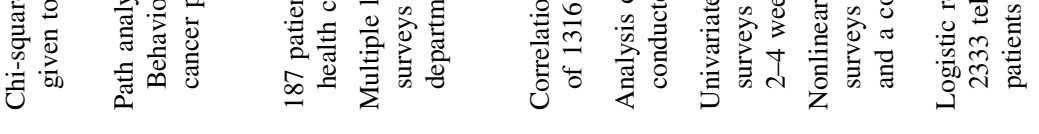

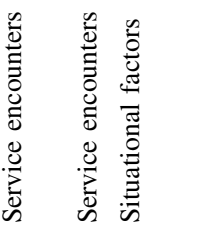

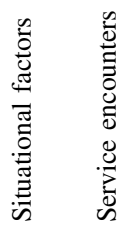

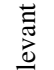

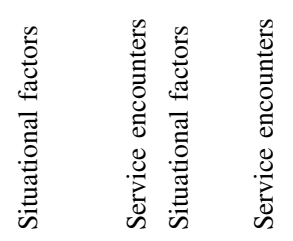

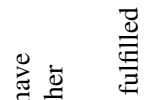

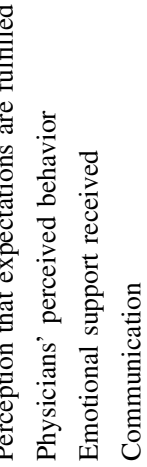

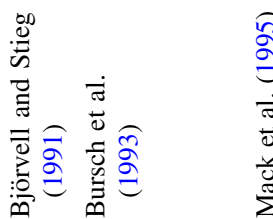

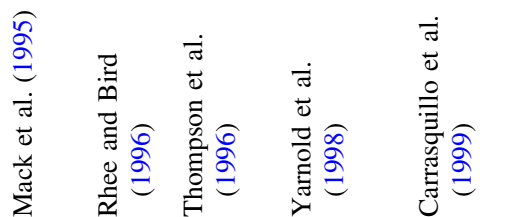




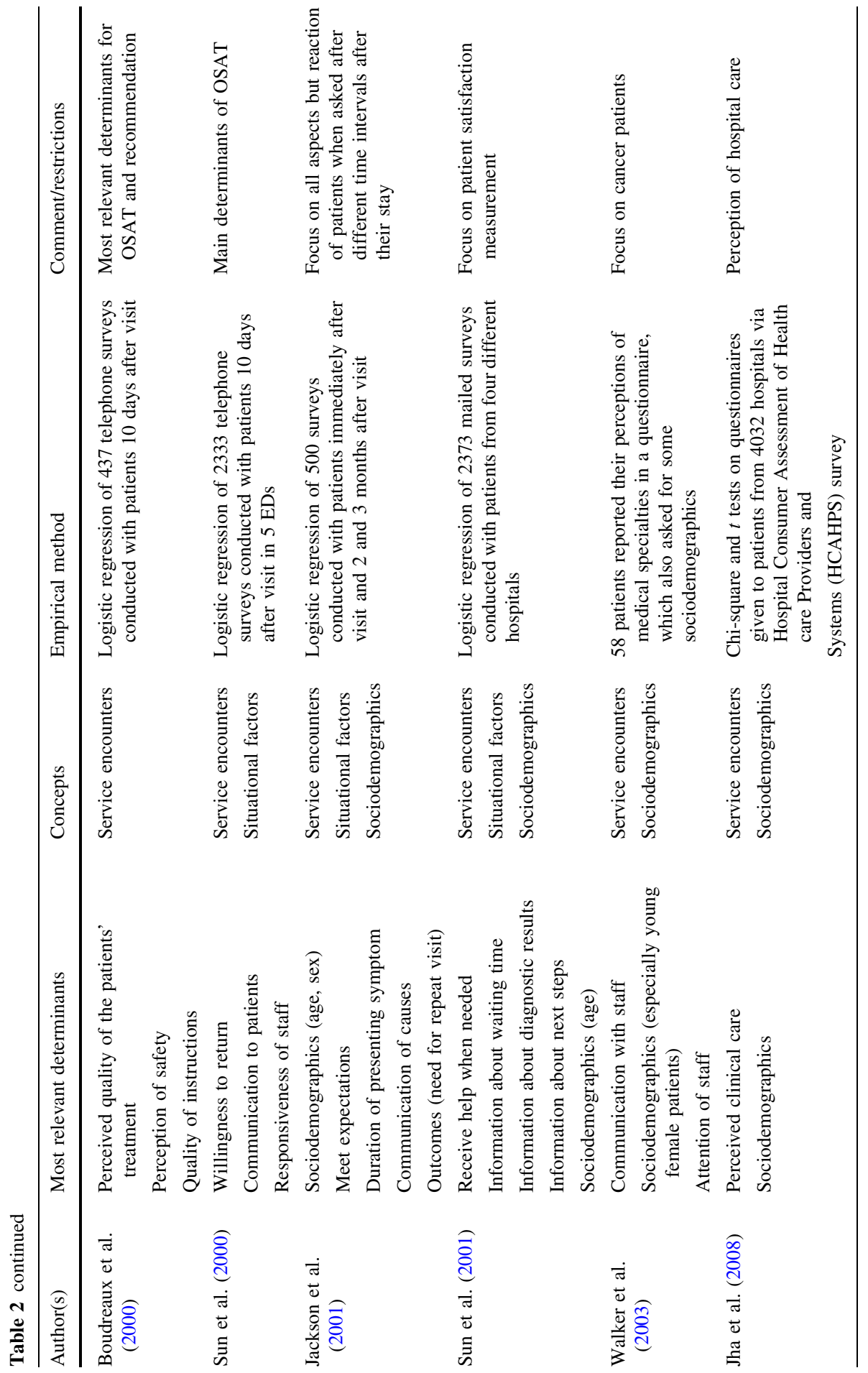




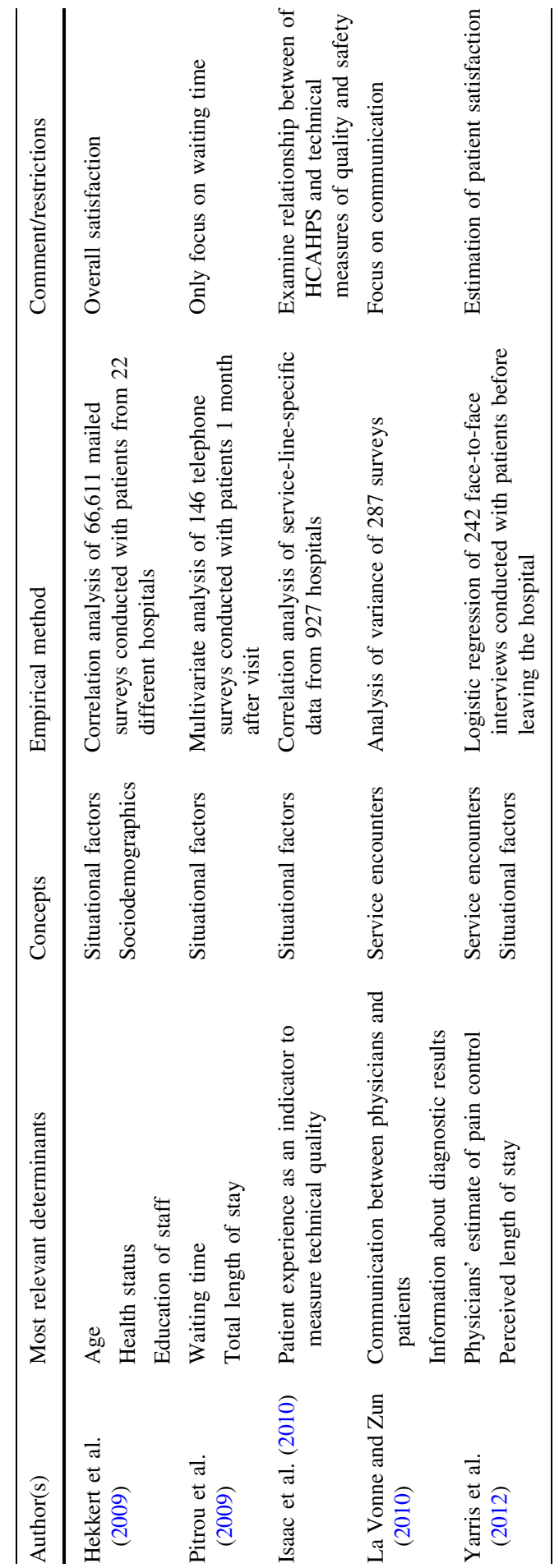


satisfaction in the literature (Devaraj et al. 2001; Hünecke and Gunkel 2012). A defect that is not fixed during the first attempt is a service failure that may require a repeat attempt to be repaired. Samuels et al. (1983) were among the first to show the high rate of dissatisfaction with repeat auto repairs and their importance in this industry. Especially in the automotive sector, facility- or car-related situational factors were frequently captured by surveys, such as the appearance of the service area or cleanliness of the car (Jones and Sasser 1995; Yieh et al. 2007). Whether or not service use was voluntary (for example, car breakdown) has been identified as an additional important situational factor (Meinzer et al. 2010; Ravald and Grönroos 1996; Samuels et al. 1983).

In the automotive sector, sociodemographics such as sex have been identified as having a significant influence on satisfaction (Darley et al. 2008). This study found that women who perceived contact with salespeople as being positive were satisfied with different aspects of their service encounter. The distinction between private or business use was examined as a relevant determinant because value for money is closely related to the purpose of car use (Bloemer and Lemmink 1992). Cultural differences based on the country of origin were identified by Hünecke and Gunkel (2012). Devaraj et al. (2001) found that they needed to control for sociodemographics such as age and income to measure perceived satisfaction accurately. They found that older people were more satisfied with the service encounters than younger people were. It is useful for the automotive industry to examine these sociodemographics (Homburg and Giering 2001; Verhoef 2003) because they show an impact on perceived satisfaction.

The most important determinants for perceived customer satisfaction in the automotive industry are summarized in Table 1.

\subsection{Literature review of the customer satisfaction determinants in the health care sector}

In health care, determinants from service encounters such as the communication or information transfer between patients and clinical staff show the highest relevance because they are mentioned most frequently, as shown in Table 2.

The health care literature recommends starting with administrative information, and providing information about forthcoming steps (Björvell and Stieg 1991; Sun et al. 2001) or expected waiting time (Sun et al. 2001). Satisfaction with information delivery in general is often included in empirical surveys in the health care sector (Blanchard et al. 1990; La Vonne and Zun 2010; Sun et al. 2000; Walker et al. 2003; Yarnold et al. 1998). Providing an explanation of diagnostic results shows transparency about the patients' current situation and it was identified in the literature several times as predicting satisfaction (Jackson et al. 2001; La Vonne and Zun 2010; Sun et al. 2001). The fundamental role of patient interaction was examined by Andaleeb (1998, 2001), Brody et al. (1989) and Crawford et al. (2002), who considered how to involve patients in the process to improve their perceived outcome. Brody et al. (1989) demonstrated that patients need to play an active role to increase their service satisfaction. Bendall-Lyon and Powers (2004) described the importance of addressing and capturing service characteristics as perceived by 
patients. Beside communication, other issues are captured by the literature, with perceived quality determinants leading the way (Boudreaux et al. 2000; Jha et al. 2008; Rhee and Bird 1996).

Situational factors are significantly relevant for the health care sector. The highest satisfaction is achieved if the waiting time is shorter than the consumer expects (Boudreaux et al. 2000; Sitzia and Wood 1997; Thompson et al. 1996) because waiting is a significant critical event, especially in urgent situations (Mack et al. 1995), and means a reduction in perceived quality (Pitrou et al. 2009; Sun et al. 2001). Thompson et al. (1996) examined the different effects of perceived and actual waiting time, and found that perceived waiting time was more important. This differentiation is also valid for the length of stay as another important situational factor (Boudreaux et al. 2000; Hall and Press 1996). Whether a visit was forced or voluntary was found to be highly significant, especially for health care (Dabholkar and Thorpe 1994). Time-related determinants are the most important predictor of perceived consumer satisfaction among the situational factors. They are highly prominent in the health care literature.

In most of the health care studies, sociodemographic information was captured by patient satisfaction questionnaires (Blanchard et al. 1990; Sun et al. 2000; Walker et al. 2003). Patient data such as age, sex, domicile, marital status, race, education level, and level of income are influencing factors (Venn and Fone 2005). Clear dependencies between these determinants and patient satisfaction were observed (Baker and Cameron 1996; Jha et al. 2008; Sun et al. 2000). Especially in critical events, language barriers may result in service failures due to failed communication, especially in health care (Carrasquillo et al. 1999). Thus, it is essential to capture sociodemographics when determining perceived consumer satisfaction in the health care sector.

The most significant determinants for perceived customer satisfaction in the health care sector are summarized in Table 2.

\subsection{Conclusions from the conceptual framework}

To generate a holistic overview about the concepts explained above, we carried out a full literature review. Tables 1 and 2 summarize the most prominent determinants for the determination of perceived consumer satisfaction in the automotive industry and the health care sector, according to the three concepts. To validate the determinants identified from the literature, the empirical methods, together with potential limitations, are listed. We reviewed 20 studies from health care and 11 from the automotive industry.

The key principle of this literature review was a systematic identification and consideration of the relevant studies and articles dealing with perceived satisfaction. Our search strategy was based on established procedures (Dickersin et al. 1994; Robinson and Dickersin 2002) using Ovid and PubMed. EBSCOhost was used for the literature review on the automotive industry. The search strategy was based on a three-phase algorithm. In the first search phase, satisfaction determination based on consumer perceptions was used as a key identifier to find articles that provide a general overview. This literature was reviewed for the specific perceptions 
Table 3 Concepts, labels, and scales from the BMW survey

\begin{tabular}{lll}
\hline Concepts & Labels & Scales \\
\hline Service encounter & SATISFACTION_SERVICE_ADVISOR* & $1-10$ \\
& SATISFACTION_VALUING_SERVICE* & $1-10$ \\
& RECOMMENDATION_PROB & $0-1$ \\
& SATISFACTION_QUALITY_OF_WORK & $1-10$ \\
& SATISFACTION_SERVICE_COMFORT & $1-10$ \\
Situational factors & INFO_DELAY** & $0-1$ \\
& LENGTH_OF_STAY & Individual \\
& SATISFACTION_CLEANLINESS & $1-10$ \\
& READINESS_CAR_ON_TIME & $0-1$ \\
& SATISFACTION_TIME_CASHIER & $1-10$ \\
Sociodemographics & SATISFACTION_APPOINTMENT & $1-10$ \\
Automotive specific & SATISFACTION_ALTERNATE_TRANSPORTATION & $1-10$ \\
& DOMICILE** & Individual \\
& ALTERNATE_TRANSPORTATION_NEEDED & $0-1$ \\
\hline
\end{tabular}

* VIF value over 4.0; ** excluded from analysis

determining consumers' satisfaction. Those specific perceptions (for example, service encounters as key driver for satisfaction) were used as further identifiers for phase two. In the third phase, specific literature was identified to prove the specific hypothesis and gain in-depth understanding about specific issues. To improve the quality, we preferred highly ranked and frequently cited literature where possible.

The most often measured and analyzed concept in both sectors is the service encounter. In the automotive business especially, service encounters are strongly related to perceived quality and satisfaction because of the high levels of technical requirements, in terms of services and repairs ( $\mathrm{Yu}$ et al. 2005). The second most frequently examined concept was situational factors followed by sociodemographics. To examine the most significant determinants for the automotive sector, we performed an empirical analysis on an existing survey from the German premium car manufacturer BMW.

\section{Methodology: Empirical test of literature comparison}

Service industries have a significant impact on the economic situation in the United States. Around $60 \%$ of the annual gross domestic product (GDP) is from service industries and nearly $70 \%$ of jobs (An and Noh 2009; McKee 2008). This section uses a survey from the automotive industry as a representative example for service industries to identify the need for action in determining perceived customer satisfaction. The most important determinants for the automotive industry are identified for each concept, employing a multiple linear regression, along with managerial implications. 


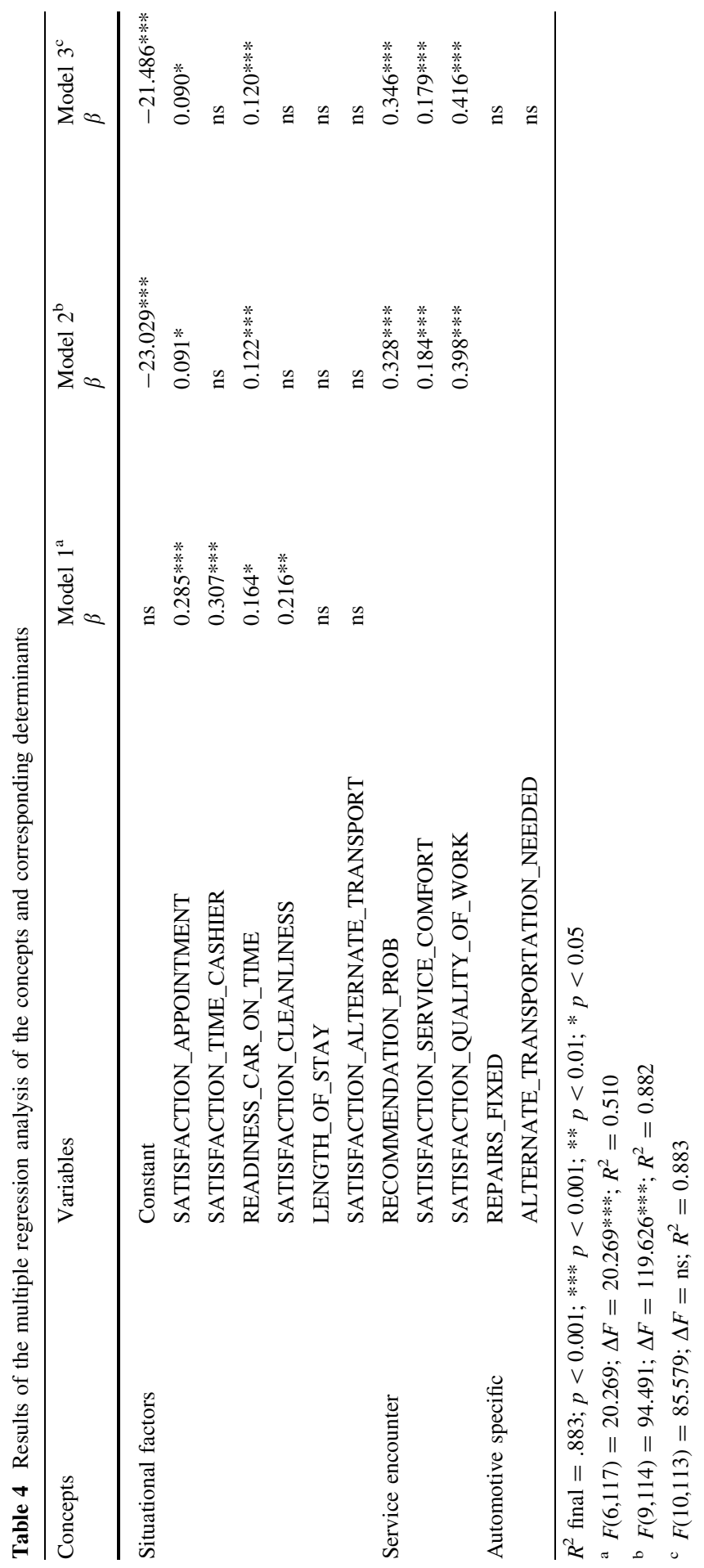


Table 5 Results of the independent sample $t$ test of the delay communication

\begin{tabular}{|c|c|c|c|c|c|c|}
\hline \multirow{2}{*}{$\begin{array}{l}\text { Group } \\
\text { Variable }\end{array}$} & \multicolumn{2}{|c|}{ Delay communicated $=$ yes } & \multicolumn{2}{|c|}{ Delay communicated $=$ no } & \multicolumn{2}{|l|}{$t$ test } \\
\hline & Mean & SD & Mean & SD & $t$ & $p$ \\
\hline Satisfaction & 80.15 & 25.15 & 48.61 & 28.00 & $10.387^{\mathrm{a}}$ & 0.000 \\
\hline
\end{tabular}

${ }^{a}$ Unequal variances; $t$ test corrected

\subsection{Procedure and sample}

We used an existing survey of BMW, an internationally operating premium automotive manufacturer. It determines customer satisfaction based on service visits in the United States. The questions were categorized into the three concepts identified from the literature review (service encounter, situational factors, and sociodemographics). A fourth concept defined as automotive-specific determinants captures the technical components of the survey.

We used survey data from 3219 car users in the United States who responded to a questionnaire between January and March 2011. For each question, either Likert-type scales from 1 to $10(1=$ very low performance to $10=$ very high performance $)$ or a binary coding $(0=$ no and $1=$ yes $)$ was employed. In total, 16 questions were asked that covered several categories of established processes a customer might notice during a service visit. The concepts, associated determinants, and scales are listed in Table 3.

\subsection{Sample selection}

The distribution of customers' domicile was very imbalanced in the survey responses. The influence of the sociodemographic factor domicile therefore could not be analyzed immediately. A stratified sample selection was conducted that normalized the results so that every domicile in the survey appeared relatively similar. The optimal sample size with a power of 0.99 was calculated to be $N=379$ (Faul et al. 2007). The calculation of the power was based on the results of an $F$ test, with an effect size of $f^{2}=0.1$, a significance level of $\alpha=0.05$, and $\beta=0.95$.

\subsection{Analysis}

Multiple linear regression models were calculated for the sample set to determine the relationship between the overall satisfaction and the various concepts and the corresponding determinants are shown in Table 3. To prevent multicollinearity, a variance inflation factor VIF value was calculated within the multiple linear regression. Determinants were only considered where the VIF value was below 4.0. The assumption of the normality of the error distribution in multiple linear regression (regarding the proper calculation of test statistics) is supported by the central limit theorem, which is especially true for larger sample sizes. Even for small sets of samples, multiple linear regression is very robust (Osborne and Waters 2002). Only one determinant within the service encounter concept captured the 
information transfer: information about a delayed service. Because delaying the service of a car is a very infrequent event, the responses show a high number of missing values, making it necessary to exclude this determinant from the multiple linear regression and analyze its impact separately in an independent sample $t$ test. Finally, 11 determinants were used for the regression analysis. In the multiple linear regression, each concept was analyzed separately to identify its impact. The analysis was conducted with SPSS Statistics version 20.0.

\section{Results of the survey analysis}

Table 4 shows the results of the multiple linear regressions, including the beta estimates. The $F$-change $(\Delta F)$ expresses the effect of the significance increase that results from the parameters added to the model. It shows the impact of an added concept on the overall satisfaction. The R-square describes the amount of total variance that is explained by the general model. Table 5 shows the results of the independent $t$ test to identify the impact of the communication within the service encounters concept.

\subsection{Impact of concepts on the overall satisfaction}

The first model of the multiple linear regression covers the determinants that are considered to be situational factors (model 1). The six corresponding questions of the survey showed an increase of significance of $\Delta F=20.269$ and a total amount of explained variance of $R^{2}=0.510$. Adding service encounter (model 2), the performance of the overall model increased significantly by $\Delta F=94.491$ and resulted in a $R^{2}=0.882$. In model 3 , the automotive-specific determinants were added, which showed a non-significant change of the overall model. All three models resulted in the best performance of $R^{2}=0.883$.

The highest variance of the dependent variable overall satisfaction was explained by model 2 , the service encounter. The situational factors consolidated in model 1 were also significantly relevant for the overall satisfaction. The automotive-specific determinants in model 3 were not significant in explaining overall satisfaction. The only sociodemographic determinant used by BMW was the state of domicile of the customer. This parameter was used for the stratified sampling to secure an equally distributed sample, and it was therefore not possible to analyze it in its own right. To get a deeper understanding of the most important determinants, the models were observed in detail.

\subsection{Impact of the determinants on overall satisfaction}

To identify the most significant and thus important determinants for overall satisfaction, we analyzed the complete linear regression model, including all three concepts (situational factors, service encounter, and automotive-specific determinants), as shown in Table 3. The findings and key drivers for perceived overall satisfaction at BMW are covered below. 


\subsubsection{Model 1: Situational factors}

The most important determinant of overall satisfaction among situational factors is the satisfaction with the time needed at the cashier $(\beta=0.307)$. The second most important issue is satisfaction with the ease of getting an appointment $(\beta=0.285)$. Both determinants are time related. They are followed by satisfaction with the cleanliness of the car after the service visit $(\beta=0.216)$ and the readiness of the car on time as promised by the dealer $(\beta=0.164)$. The length of stay of the car at the dealer and satisfaction with alternative transportation showed no significant results.

\subsubsection{Model 2: Situational factors and service encounters}

The second model included all determinants that correspond to the concepts of situational factors or service encounters. The satisfaction with the time needed at the cashier was no longer significant, and neither was satisfaction with the cleanliness of the car. The significance and importance of satisfaction with the ease of getting an appointment decreased to $\beta=0.091$. The importance of the readiness of the car on time as promised by the dealer decreased as well, but was still the most significant determinant among the situational factors in this model $(\beta=0.122)$. The length of stay of the car at the dealer and the satisfaction with the alternate transportation still showed no significant results.

However, the additional concept of service encounters increased the significance of the overall model. The quality of work performed was the most important determinant in this model $(\beta=0.398)$, followed by the willingness of the customer to recommend the dealer $(\beta=0.328)$. The third most important determinant was also part of the service encounters, the satisfaction with the service comfort that is provided by the dealer $(\beta=0.184)$.

\subsubsection{Model 3: Situational factors, service encounters, and automotive-specific determinants}

The third model combined all the identified concepts in the questionnaire to explain the overall satisfaction. It had the highest value, as already identified and shown in Table 3 .

The satisfaction with perceived service quality of work performed still showed the highest impact $(\beta=0.416)$, followed by the willingness of the customer to recommend the dealer $(\beta=0.346)$, and satisfaction with the service and comfort $(\beta=0.179)$. All three correspond to the concept of service encounters. From the situational factors, like model 2 , the readiness of the car on time as promised by the dealer $(\beta=0.120)$ and the satisfaction with the ease of getting an appointment $(\beta=0.090)$ were most significant.

The automotive-specific determinants about whether alternate transportation was needed and if the repairs were fixed the first time showed no significant impact on the overall satisfaction in the linear regression model. 


\subsection{Impact of the communication of a delay on overall satisfaction}

The only determinant within the service encounters concept that covered the communication between customers and staff was information about the delay of a service. As described earlier, it was necessary to analyze the impact of this determinant separately because it was an optional question, answered only if the car was not ready when promised. The information transfer showed significant influence on overall satisfaction, shown in Table 5. The results revealed a significant difference between customers who were told about the delay of the service before they went back to pick up their car (average satisfaction of 80.15) and customers who were not told about the delay beforehand (average satisfaction of 48.61). The impact of a delay and the timing of the communication therefore seem to be important determinants in controlling critical events.

\section{Implications for the automotive industry based on the findings from BMW}

In our literature review, we tested and confirmed the hypothesis that the determinants to capture perceived consumer satisfaction in health care are closely related to those in the automotive industry. They can be split into the same three concepts: service encounter, situational factors, and sociodemographics. However, analysis of the BMW survey shows potential for improvements to capture satisfaction. In the following section, we will examine how to make the necessary changes, and present the established benefits for this premium German car manufacturer based on the empirical and literature findings. The positive impact of an increase of consumer satisfaction on loyalty has already been identified for BMW (Walter et al. 2013).

\subsection{Options for improvement for the service encounter concept}

Managers working in the after-sales segment of the premium car manufacturer BMW should focus intensively on the communication between service advisors and the customer, because these determinants were identified as the most important for customer satisfaction. Our empirical analyses support the findings from our literature review, that service encounter is the most important concept to determine perceived consumer satisfaction because it shows the highest share of variance explained. At BMW, information about administrative issues and explanations of the results from the service is not currently covered by the survey. Especially in health care, these determinants are identified as significant predictors of perceived satisfaction. Therefore, BMW should capture this information to understand the most significant service process-related determinants. Willingness to recommend the dealer and satisfaction with service comfort were the second and third most significant items within this concept after the quality of work performed. Informed customers show much higher satisfaction levels. The significant impact of service failure and the effect of active communication are shown in Table 5. 
Additionally, time-related service encounters are identified as highly relevant to prevent a decrease in satisfaction, for example, from having to wait. BMW already captures the communication of the delay and is therefore able to analyze the impact of this service failure. However, there is still room for improvement. The current time-related question is only asked if there is a delay. To understand how best to communicate any delays or additional waiting time, BMW should ask for customers' preferred communication channel. A personalized communication strategy could then be implemented, which is better for effective customer relationship management. The consequences of service failures at BMW, and the importance of capturing these, were shown by a case of delayed parts delivery that increased waiting times (Maier and Weiss 2013). BMW could also benefit from asking a question about satisfaction with explanations of the invoice.

Perceived value for money plays an important role in the automotive sector. Particularly if customers are paying for their own service or repair, BMW should focus on a detailed explanation of the charges. This item is currently captured in satisfaction with the value provided by the service, which provides important information about how well the company meets consumer expectations of value for money.

Based on our empirical analysis, the quality of work performed is the most important element of this concept, which matches the literature findings and our assumption that service quality is an antecedent of consumer satisfaction. BMW captures this information by asking about the quality of work performed, providing an insight into performance. They are also able to compare these findings with data received from other cars and dealers (IBM 2013; Meinzer et al. 2012b). Consequently, BMW should continue and try to extend these capabilities.

\subsection{Implications for an improved measurement of situational factors}

Situational factors have the second highest impact on the overall satisfaction in our empirical analysis. The most important determinants identified for situational factors are time related, with waiting time being the most prominent. The health care sector showed that waiting time is a critical factor in consumer treatment and needs to be seen as a service failure whenever it exceeds the customer's expectation. BMW captures this determinant in detail via questions about the readiness of the car when promised, the time with the cashier, and satisfaction with how long it takes to get an appointment. The readiness of the car on time was the most important determinant to measure the overall satisfaction in our empirical model. However, there is still room for improvement. From health care, we also learned that the waiting time until first contact is also significant. We therefore recommend asking about the waiting time after arrival as well, to cover the whole service process. In line with Thompson et al. (1996), we also suggest that BMW should differentiate between perceived and actual waiting time. The perceived length of stay is already captured in the survey, but did not show a significant impact in the linear regression model. An improvement could be achieved by differentiating between actual and perceived length of stay. This minor change would cover all the most important time-related items. 
The perception of the appearance of service advisors and the service institution itself was considered important in our literature review, but did not show a significant impact on customer satisfaction. The BMW survey includes satisfaction with the cleanliness of the car. We would also suggest asking about the appearance of the service advisor and the dealership in general to understand whether this impact is important to perceiving consumer satisfaction.

\subsection{Better customer understanding through the concept of sociodemographics at BMW}

The only sociodemographic determinant currently included is the state of residence of the customer, and it was used as the basis for stratified sampling. Therefore, separately evaluating its impact was not possible. To customize consumer treatment, a more precise knowledge of their sociodemographics is needed. BMW may therefore need to find a way to include more determinants from this concept. Bloemer and Lemmink (1992) identified the dealer's knowledge about the consumer's car use, whether private or business, as a significant determinant. Currently, BMW can only get such information from their own business fleets or potential public sources. We recommend that this determinant be specifically included in the survey.

BMW should also capture the age and sex of their service consumers, which have been examined as significant determinants in our literature review. Such information would help BMW to steer their individualized customer treatment centrally and not only via the dealerships, which are currently the institutions that know the customers best.

BMW should also find a way to measure customers' preferred communication channels to improve the customer relationship management. Cooil et al. (2007) and Keaveney and Parthasarathy (2001) observed that better educated customers ask for additional information to support their decision making. Therefore, we recommend that this sociodemographic determinant be captured.

BMW should try to analyze more sociodemographic determinants, provided that their customers and dealers agreed to provide this information. The significance of sociodemographic factors in optimizing customer care is supported by the literature unequivocally, and is especially important for the after-sales processes in the automotive industry. Sociodemographics is certainly a critical concept to analyze from a data privacy perspective and it is therefore important to be aware of national policies.

\subsection{Extending the capability to match automotive-specific determinants with internal BMW technical data}

The BMW survey captures two automotive-specific determinants. Customers are asked whether they need alternate transport and whether the repair was done right the first time. The automotive-specific determinants did not show a significant impact in the empirical analysis. However, our literature review proved that knowledge about previous repeat repairs was essential because these are seen as critical events. Consumers were especially dissatisfied when their cars had a high rate of repeat repairs, defined as repairs caused by a similar technical problem or a 
perceived identical cause (Biehal 1983; Kohl et al. 2011; Meinzer et al. 2010). The gap between perceived service failures such as repeat repairs and the technical image that BMW wishes to convey is particularly important (Meinzer et al. 2012b). BMW is already able to capture a huge amount of technical data, including warranty or diagnostic information (IBM 2013), which enable the measurement of repeat repairs in the technical data. However, the repeat repair rate from a customer's perspective is significantly higher than the measures based on warranty or diagnostic data (Meinzer et al. 2012b). Matching this automotive-specific determinant from the survey with the technical data transferred from the cars and the dealers, BMW is able to interpret technical measures from a customer's perspective (Meinzer et al. 2012a). BMW should extend these capabilities to those processes that are measured by internal key performance indicators with high customer focus. This would reduce the gap between technical, objective measures, and subjective customer-perceived feedback. An in-depth analysis about technical drivers for dissatisfaction could also be achieved.

\section{Limitations and future research}

In this article, we have provided an overview of the determinants that best measure the perceived consumer satisfaction in health care and the automotive industry. The results were derived from our literature review of both industries and an analysis of a survey conducted by the premium car manufacturer BMW and they confirm that findings from the health care industry can be adapted to the automotive industry. We have drawn out the practical implications, particularly the possible adaptations and improvements based on the health care findings. However, some important general limitations should be considered when interpreting our findings.

First, we chose BMW as a representative example of the automotive industry. The survey was an established questionnaire used to determine satisfaction. Further research should include surveys from other companies to broaden the understanding of our findings and to verify their generalizability.

Second, the survey was carried out in the United States and there may be significant cultural differences in other countries. Further research is needed to analyze survey results from other countries to test this. This consideration could be especially relevant for the automotive industry because car types and models, and consequently customer expectations, differ across and within countries.

Third, we only examined the applicability of the information transfer to the automotive industry. Further research should also consider other industries to investigate the generalizability of our findings for the service sector as a whole.

\section{Conclusion}

Our results demonstrate that insights about determination of patient satisfaction in health care can be transferred to the automotive industry. Three concepts were derived from the health care literature and analyzed for their applicability to the automotive 
industry. These were service encounter, situational factors, and sociodemographics. This cross-sector knowledge transfer is possible because there are universally applicable determinants, which can be transferred from health care to the automotive sector. By transferring those determinants, it is possible to generate a description of status quo, detect drivers for change, and allow predictions of perceived satisfaction. This allows knowledge of the health care sector to be used by managers in companies in other industrial sectors. The automotive industry can enhance their determination of perceived consumer satisfaction by improving their established questionnaires. By adapting the presented approach, the missing determinants can be identified immediately. Therefore, all after-sales service processes can be monitored from the customers' perspective and be improved sustainably.

\section{Compliance with Ethical Standards}

Conflict of interest None of the authors of this manuscript has declared any conflict of interest which may arise from being named as an author on the manuscript.

Open Access This article is distributed under the terms of the Creative Commons Attribution 4.0 International License (http://creativecommons.org/licenses/by/4.0/), which permits unrestricted use, distribution, and reproduction in any medium, provided you give appropriate credit to the original author(s) and the source, provide a link to the Creative Commons license, and indicate if changes were made.

\section{References}

An M, Noh Y (2009) Airline customer satisfaction and loyalty: impact of in-flight service quality. Serv Bus 3(3):293-307

Andaleeb SS (1998) Determinants of customer satisfaction with hospitals: a managerial model. Int J Health Care Qual Assur 11(6):181-187

Anderson RE (1973) Consumer dissatisfaction: the effect of disconfirmed expectancy on perceived product performance. J Mark Res 10(1):38-44

Anderson EW, Sullivan MW (1993) The antecedents and consequences of customer satisfaction for firms. Mark Sci 12(2):125-143

Anderson EW, Fornell C, Lehmann DR (1994) Customer satisfaction, market share, and profitability: findings from Sweden. J Mark 58(3):53-66

Anderson EW, Fornell C, Mazvancheryl SK (2004) Customer satisfaction and shareholder value. J Mark 68(4):172-185

Archer NP, Wesolowsky GO (1996) Consumer response to service and product quality: a study of motor vehicle owners. J Oper Manag 14(2):103-118

Arthur D. Little-Automotive INSIGHT (2015) Automotive after sales 2015: are you ready for the battle? Arthur D. Little, Germany. http://www.adlittle.com/downloads/tx_adlreports/AMG_ Automotive_after_sales_2015_01.pdf

Bagozzi RP (1978) Salesforce performance and satisfaction as a function of individual difference, interpersonal, and situational factors. J Mark Res 15(4):517-531

Baker J, Cameron M (1996) The effects of the service environment on affect and consumer perception of waiting time: an integrative review and research propositions. J Acad Mark Sci 24(4):338-349

Bei L-T, Chiao Y-C (2001) An integrated model for the effects of perceived product, perceived service quality, and perceived price fairness on consumer satisfaction and loyalty. J Consumer Satisf Dissatisf Complain Behav 14:125-140

Bendall-Lyon D, Powers TL (2004) The impact of structure and process attributes on satisfaction and behavioral intentions. J Serv Mark 18(2):114-121

Bennett R, Rundle-Thiele S (2004) Customer satisfaction should not be the only goal. J Serv Mark 18(7):514-523 
Bettencourt LA (1997) Customer voluntary performance: customers as partners in service delivery. J Retail 73(3):383-406

Biehal GJ (1983) Consumers' prior experiences and perceptions in auto repair choice. J Mark 47(3):82-91

Bitner MJ, Booms BH, Tetreault MS (1990) The service encounter: diagnosing favorable and unfavorable incidents. J Mark 54(1):71-84

Bitner MJ, Booms BH, Mohr LA (1994) Critical service encounters: the employee's viewpoint. J Mark 58(4):95-106

Bitner MJ, Faranda WT, Hubbert AR, Zeithaml VA (1997) Customer contributions and roles in service delivery. Int J Serv Ind Manag 8(3):193-205

Björvell H, Stieg J (1991) Patients' perceptions of the health care received in an emergency department. Ann Emerg Med 20(7):734-738

Blackwell SA, Szeinbach SL, Barnes JH, Garner DW, Bush V (1999) The antecedents of customer loyalty an empirical investigation of the role of personal and situational aspects on repurchase decisions. J Serv Res 1(4):362-375

Blanchard CG, Labrecque MS, Ruckdeschel JC, Blanchard EB (1990) Physician behaviors, patient perceptions, and patient characteristics as predictors of satisfaction of hospitalized adult cancer patients. Cancer 65(1):186-192

Blanchard C, Comm CL, Mathaisel DFX (2008) Adding value to service providers: benchmarking WalMart. Benchmarking 15(2):166-177

Blocker CP, Flint DJ, Myers MB, Slater SF (2011) Proactive customer orientation and its role for creating customer value in global markets. J Acad Mark Sci 39(2):216-233

Bloemer JMM, Lemmink JGAM (1992) The importance of customer satisfaction in explaining brand and dealer loyalty. J Mark Manag 8(4):351-363

Bloemer JM, Pauwels KH (1998) Explaining brand loyalty, dealer sales loyalty and dealer after-sales loyalty: the influence of satisfaction with the car, satisfaction with the sales service and satisfaction with the after-sales service. J Consumer Satisf Dissatisf Complain Behav 11:78-90

BMW (2014) Statement Dr. Norbert Reithofer, Chairman of the Board of Management of BMW AG. https://www.press.bmwgroup.com/global/pressDetail.html?title=statement-dr-norbert-reithoferchairman-of-the-board-of-management-of-bmw-ag-conference-call-interim\&outputChannelId $=6 \&$ id=T0179284EN\&left_menu_item=node_807

Boudreaux ED, Ary RD, Mandry CV, McCabe B (2000) Determinants of patient satisfaction in a large, municipal ED: the role of demographic variables, visit characteristics, and patient perceptions. Am J Emerg Med 18(4):394-400

Boulding W, Staelin R, Ehret M, Johnston WJ (2005) A customer relationship management roadmap: what is known, potential pitfalls, and where to go. J Mark 69(4):155-166

Bouman M, Van der Wiele T (1992) Measuring service quality in the car service industry: building and testing an instrument. Int J Serv Ind Manag 3(4):4-16

Brito EPZ, Aguilar RLB, Brito LAL (2007) Customer choice of a car maintenance service provider: a model to identify the service attributes that determine choice. Int J Oper Prod Manag 27(5):464-481

Brody D, Miller S, Lerman C, Smith D, Caputo G (1989) Patient perception of involvement in medical care. J Gen Intern Med 4(6):506-511

Brown S, Gulycz M (2006) Performance driven CRM: how to make your customer relationship management vision a reality. Wiley, Toronto

Brown SW, Swartz TA (1989) A gap analysis of professional service quality. J Mark 53(2):92-98

Bursch B, Beezy J, Shaw R (1993) Emergency department satisfaction: what matters most? Ann Emerg Med 22(3):586-591

Carrasquillo O, Orav E, Brennan T, Burstin H (1999) Impact of language barriers on patient satisfaction in an emergency department. J Gen Intern Med 14(2):82-87

Caruana A (2002) Service loyalty: the effects of service quality and the mediating role of customer satisfaction. Eur J Mark 36(7/8):811-828

Cheng L-Y, Yang C-W (2013) Conceptual analysis and implementation of an integrated CRM system for service providers. Serv Bus 7(2):307-328

Chojnacki K (2000) Relationship marketing at Volkswagen. In: Hennig-Thurau T, Hansen U (eds) Relationship marketing. Springer, New York, pp 49-58. doi:10.1007/978-3-662-09745-8_3

Chuang S-C, Cheng Y-H, Chang C-J, Yang S-W (2012) The effect of service failure types and service recovery on customer satisfaction: a mental accounting perspective. Serv Ind J 32(2):257-271 
Churchill GAJ, Surprenant C (1982) An investigation into the determinants of customer satisfaction. J Mark Res 19(4):491-504

Cooil B, Keiningham TL, Aksoy L, Hsu M (2007) A longitudinal analysis of customer satisfaction and share of wallet: investigating the moderating effect of customer characteristics. J Mark 71(1):67-83

Corbin CL, Kelley SW, Schwartz RW (2001) Concepts in service marketing for healthcare professionals. Am J Surg 181(1):1-7

Crawford MJ, Rutter D, Manley C, Weaver T, Bhui K, Fulop N, Tyrer P (2002) Systematic review of involving patients in the planning and development of health care. BMJ 325(7375):1263

Cronin JJJ, Taylor SA (1992) Measuring service quality: a reexamination and extension. J Mark 56(3):55-68

Cronin JJJ, Brady MK, Hult GTM (2000) Assessing the effects of quality, value, and customer satisfaction on consumer behavioral intentions in service environments. J Retail 76(2):193-218

Dabholkar P, Bagozzi R (2002) An attitudinal model of technology-based self-service: moderating effects of consumer traits and situational factors. J Acad Mark Sci 30(3):184-201

Dabholkar PA, Thorpe DI (1994) Does customer satisfaction predict shopper intentions. J Consumer Satisf Dissatisf Complain Behav 7(1):161-171

Darby C, Hays RD, Kletke P (2005) Development and evaluation of the CAHPS ${ }^{\circledR}$ hospital survey. Health Services Research 40(6p2):1973-1976

Darley WK, Luethge DJ, Thatte A (2008) Exploring the relationship of perceived automotive salesperson attributes, customer satisfaction and intentions to automotive service department patronage: the moderating role of customer sex. J Retail Consumer Serv 15(6):469-479

Deng WJ, Yeh ML, Sung ML (2013) A customer satisfaction index model for international tourist hotels: integrating consumption emotions into the American Customer Satisfaction Index. Int J Hosp Manag 35:133-140

Devaraj S, Matta KF, Conlon E (2001) Product and service quality: the antecedents of customer loyalty in the automotive industry. Prod Oper Manag 10(4):424-439

Dickersin K, Scherer R, Lefebvre C (1994) Systematic reviews: identifying relevant studies for systematic reviews. BMJ 309(6964):1286-1291

Dong B, Evans KR, Zou S (2008) The effects of customer participation in co-created service recovery. J Acad Mark Sci 36(1):123-137

Dong S, Ding M, Grewal R, Zhao P (2011) Functional forms of the satisfaction-loyalty relationship. Int J Res Mark 28(1):38-50

Dünzl H, Kirylak L (1997) Fokussierung auf den Kunden - Das Premier Customer Care-Programm von BMW in den USA. In: Simon H, Homburg C (eds) Kundenzufriedenheit. Gabler Verlag, Wiesbaden, pp 435-445. doi:10.1007/978-3-663-13219-6_21

Faul F, Erdfelder E, Lang A-G, Buchner A (2007) G*Power 3: a flexible statistical power analysis program for the social, behavioral, and biomedical sciences. Behav Res Methods 39(2):175-191

Flint DJ, Blocker CP, Boutin PJ Jr (2011) Customer value anticipation, customer satisfaction and loyalty: an empirical examination. Ind Mark Manage 40(2):219-230

Forbes (2013) The world's most valuable brands. Forbes Media LLC. http://www.forbes.com/powerfulbrands/list/

Ford WZ (2001) Customer expectations for interactions with service providers: relationship versus encounter orientation and personalized service communication. J Appl Commun Res 29(1):1-29

Fornell C (1992) A national customer satisfaction barometer: the Swedish experience. J Mark 56(1):6-21

Fornell C, Johnson MD, Anderson EW, Cha J, Bryant BE (1996) The American customer satisfaction index: nature, purpose, and findings. J Mark 60(4):7-18

Frost FA, Kumar M (2000) INTSERVQUAL — an internal adaptation of the GAP model in a large service organisation. J Serv Mark 14(5):358-377

Gaiardelli P, Saccani N, Songini L (2007) Performance measurement of the after-sales service networkevidence from the automotive industry. Comput Ind 58(7):698-708

Gebauer H, Krempl R, Fleisch E (2008) Service development in traditional product manufacturing companies. Eur J Innov Manag 11(2):219-240

Gil I, Berenguer G, Cervera A (2008) The roles of service encounters, service value, and job satisfaction in achieving customer satisfaction in business relationships. Ind Mark Manage 37(8):921-939

Gilbert GR, Veloutsou C (2006) A cross-industry comparison of customer satisfaction. J Serv Mark 20(5):298-308

Gilbert GR, Roslow S, Nicholls JAF (1997) Customer satisfaction with personal service and the service setting. In: Wilson EJ, Hair JJF (eds) Proceedings of the 1997 Academy of Marketing Science 
(AMS) annual conference, 2015. Developments in marketing science. Springer, New York, pp 109-109

Giordano LA, Elliott MN, Goldstein E, Lehrman WG, Spencer PA (2009) Development, implementation, and public reporting of the HCAHPS survey. Med Care Res Rev 67(1):27-37

Grönroos C (1984) A service quality model and its marketing implications. Eur J Mark 18(4):36-44

Grönroos C (2001) The perceived service quality concept—a mistake? Manag Serv Qual 11(3):150-152

Gwinner K, Gremler D, Bitner M (1998) Relational benefits in services industries: the customer's perspective. J Acad Mark Sci 26(2):101-114

Hackl P, Scharitzer D, Zuba R (1996) The Austrian Customer Satisfaction Barometer (ACSB)—a pilot study. J Mark 35(2):86-94

Hall MF, Press I (1996) Keys to patient satisfaction in the emergency department: results of a multiple facility study. Hosp Health Serv Adm 41(4):515-532

Hare C, Law J, Brennan C (2013) The vulnerable healthcare consumer: an interpretive synthesis of the patient experience literature. Int J Consumer Stud 37(3):299-311

Hekkert KD, Cihangir S, Kleefstra SM, van den Berg B, Kool RB (2009) Patient satisfaction revisited: a multilevel approach. Soc Sci Med 69(1):68-75

Hennig-Thurau T (2004) Customer orientation of service employees: its impact on customer satisfaction, commitment, and retention. Int J Serv Ind Manag 15(5):460-478

Hennig-Thurau T, Klee A (1997) The impact of customer satisfaction and relationship quality on customer retention: a critical reassessment and model development. Psychol Mark 14(8):737-764

Herrmann A, Huber F, Braunstein C (2000) Market-driven product and service design: bridging the gap between customer needs, quality management, and customer satisfaction. Int J Prod Econ 66(1):77-96

Homburg C, Giering A (2001) Personal characteristics as moderators of the relationship between customer satisfaction and loyalty — an empirical analysis. Psychol Mark 18(1):43-66

Homburg C, Rudolph B (2001) Customer satisfaction in industrial markets: dimensional and multiple role issues. J Bus Res 52(1):15-33

Hsu S-H (2008) Developing an index for online customer satisfaction: adaptation of American Customer Satisfaction Index. Expert Syst Appl 34(4):3033-3042

Huang WY, Dubinsky AJ (2013) Measuring customer pre-purchase satisfaction in a retail setting. Serv Ind J 34(3):212-229

Hudak PL, McKeever P, Wright JG (2003) The metaphor of patients as customers: implications for measuring satisfaction. J Clin Epidemiol 56(2):103-108

Hui MK, Bateson JE (1991) Perceived control and the effects of crowding and consumer choice on the service experience. J Consumer Res 18(2):174-184

Hui MK, Tse DK (1996) What to tell consumers in waits of different lengths: an integrative model of service evaluation. J Mark 60(2):81-90

Hünecke P, Gunkel M (2012) The influence of after-sales service determinants on brand loyalty within the premium automotive industry: an empirical comparison of three countries. Serv Sci 4(4):365-381

IBM Business Analytics (2013) Boosting the satisfaction of premium car customers. IBM Corporation. http://ibm.co/1at4fKo

Isaac T, Zaslavsky AM, Cleary PD, Landon BE (2010) The relationship between patients' perception of care and measures of hospital quality and safety. Health Serv Res 45(4):1024-1040

Jackson JL, Chamberlin J, Kroenke K (2001) Predictors of patient satisfaction. Soc Sci Med 52(4):609-620

J.D. Powers (2013) 2013 U.S. Customer Service Index (CSI) study. J.D. Powers and Associates. http:// www.jdpower.com/content/press-release/gMEbEQI/2013-u-s-customer-service-index-csi-study.htm

J.D. Powers (2014) 2014 U.S. Customer Service Index (CSI) study. J.D. Powers and Associates. http:// www.jdpower.com/press-releases/2014-us-customer-service-index-csi

Jemmasi M, Strong KC, Taylor SA (2011) Measuring service quality for strategic planning and analysis in service firms. J Appl Bus Res 10(4):24-34

Jha AK, Orav EJ, Zheng J, Epstein AM (2008) Patients' perception of hospital care in the United States. N Engl J Med 359(18):1921-1931

Johnson MD, Fornell C (1991) A framework for comparing customer satisfaction across individuals and product categories. J Econ Psychol 12(2):267-286

Jones MA, Suh J (2000) Transaction-specific satisfaction and overall satisfaction: an empirical analysis. J Serv Mark 14(2):147-159 
Jones TO, Sasser WE (1995) Why satisfied customers defect. Harvard Bus Rev 73(6):1-14

Keaveney SM (1995) Customer switching behavior in service industries: an exploratory study. J Mark 59(2):71-82

Keaveney SM, Parthasarathy M (2001) Customer switching behavior in online services: an exploratory study of the role of selected attitudinal, behavioral, and demographic factors. J Acad Mark Sci 29(4):374-390

Kohl J, Kotucz A, Prenninger J, Dorneich A, Meinzer S (2011) Using multivariate split analysis for an improved maintenance of automotive diagnosis functions. In: Mens T, Kanellopoulos Y, Winter A (eds) 15th European conference on software maintenance and reengineering (CSMR), vol 15. IEEE Computer Society, Oldenburg, pp 305-308

Kristensen K, Martensen A, Gronholdt L (2000) Customer satisfaction measurement at Post Denmark: results of application of the European Customer Satisfaction Index methodology. Total Qual Manag 11(7):1007-1015

Kumar V, Pozza ID, Ganesh J (2013) Revisiting the satisfaction-loyalty relationship: empirical generalizations and directions for future research. J Retail 89(3):246-262

La Vonne AD, Zun LS (2010) The correlation between patient comprehension of their reason for hospital admission and overall patient satisfaction in the emergency department. J Natl Med Assoc 102(7):637-643

Laith A, Feras A (2011) The mediating effect of patient satisfaction in the patients' perceptions of healthcare quality-patient trust relationship. Int J Mark Stud 3(1):103-127

Lau GT, Ng S (2001) Individual and situational factors influencing negative word-of-mouth behaviour. Can J Adm Sci 18(3):163-178

Lee H, Delene LM, Bunda MA, Kim C (2000a) Methods of measuring health-care service quality. J Bus Res 48(3):233-246

Lee H, Lee Y, Yoo D (2000b) The determinants of perceived service quality and its relationship with satisfaction. J Serv Mark 14(3):217-231

Leydon GM, Boulton M, Moynihan C, Jones A, Mossman J, Boudioni M, McPherson K (2000) Cancer patients' information needs and information seeking behaviour: in depth interview study. BMJ 320(7239):909-913

Lindgreen A, Palmer R, Vanhamme J, Wouters J (2006) A relationship-management assessment tool: questioning, identifying, and prioritizing critical aspects of customer relationships. Ind Mark Manage 35(1):57-71

Mack JL, File KM, Horwitz JE, Prince RA (1995) The effect of urgency on patient satisfaction and future emergency department choice. Health Care Manage Rev 20(2):7-15

Maher JK, Marks LJ, Grimm PE (1997) Overload, pressure, and convenience: testing a conceptual model of factors influencing women's attitudes toward, and use of shopping channels. Adv Consum Res 24(1):490-498

Maier A, Weiss R (2013) BMW owners waiting for repairs on supply chain breakdown. Bloomberg. Accessed 21 August 2013. http://www.bloomberg.com/news/2013-08-20/bmw-owners-waiting-forrepairs-on-supply-chain-breakdown.html

Makarem SC, Al-Amin M (2014) Beyond the service process: the effects of organizational and market factors on customer perceptions of health care services. J Serv Res 17(4):399-414

Mangold WG, Miller F, Brockway GR (1999) Word-of-mouth communication in the service marketplace. J Serv Mark 13(1):73-89

Mattsson J (1992) A service quality model based on an ideal value standard. Int J Serv Ind Manag 3(3):18-33

McKee DL (2008) Services, growth poles and advanced economies. Serv Bus 2(2):99-107

Meinzer S, Prenninger J, Eberl M, Eren T (2010) Increase customer satisfaction and quality management by applying predictive analytics on diagnostic data. In: Heyer G, Luy JF, Jahn A (eds) Text- and data mining for quality analytics in the automotive industry. Leipziger Beiträge zur Informatik, Leipzig, pp 17-27

Meinzer S, Prenninger J, Deicke A (2012a) Qualitätsmanagement im Automobilbau ohne Datenanalyse Undenkbar. In: Eberspächer J, Wohlmuth O (eds) Big Data wird neues Wissen. Münchner Kreis Übernationale Vereinigung für Kommunikationsforschung e.V., Munich, pp 78-88

Meinzer S, Prenninger J, Eskofier B (2012b) Transferring methods and knowledge from the healthcare sector to the automotive industry to increase perceived quality and satisfaction. In: Sening W (ed) Kooperationskongress NeZuMed - Innovationen aus Wissenschaft und Zulieferindustrie für die Medizintechnik, Erlangen, Germany, June 20-21, p 109 
Meuter ML, Ostrom AL, Roundtree RI, Bitner MJ (2000) Self-service technologies: understanding customer satisfaction with technology-based service encounters. J Mark 64(3):50-64

Mittal V, Frennea C (2010) Customer satisfaction: a strategic review and guidelines for managers. http:// ssrn.com/abstract $=2345469$

Mittal B, Lassar WM (1998) Why do customers switch? The dynamics of satisfaction versus loyalty. J Serv Mark 12(3):177-194

Mittal V, Ross WT, Baldasare PM (1998) The asymmetric impact of negative and positive attribute-level performance on overall satisfaction and repurchase intentions. J Mark 62(1):33-47

Müller W (1991) Gaining competitive advantage through customer satisfaction. Eur Manag J $9(2): 201-211$

Nie W (2000) Waiting: integrating social and psychological perspectives in operations management. Int J Manag Sci 28(6):611-629

Oh H (1999) Service quality, customer satisfaction, and customer value: a holistic perspective. Int J Hosp Manag 18(1):67-82

Oliver RL (1980) A cognitive model of the antecedents and consequences of satisfaction decisions. J Mark Res 17(4):460-469

Osborne JW, Waters E (2002) Four assumptions of multiple regression that researchers should always test. Pract Assess Res Eval 8(2):1-5

Parasuraman A, Zeithaml VA, Berry LL (1985) A conceptual model of service quality and its implications for future research. J Mark 49(4):41-50

Parasuraman A, Zeithaml VA, Berry LL (1988) SERVQUAL: a multiple-item scale for measuring consumer perceptions of service quality. J Retail 64(1):12-40

Parasuraman A, Berry LL, Zeithaml VA (1991) Refinement and reassessment of the SERVQUAL scale. J Retail 67(4):420-450

Pitrou I, Lecourt A-C, Bailly L, Brousse B, Dauchet L, Ladner J (2009) Waiting time and assessment of patient satisfaction in a large reference emergency department: a prospective cohort study, France. Eur J Emerg Med 16(4):177-182

Pruyn A, Smidts A (1998) Effects of waiting on the satisfaction with the service: beyond objective time measures. Int J Res Mark 15(4):321-334

Randheer K, AL-Motawa AA (2011) Measuring commuters' perception on service quality using SERVQUAL in public transportation. Int J Mark Stud 3(1):21-34

Rao M, Clarke A, Sanderson C, Hammersley R (2006) Patients' own assessments of quality of primary care compared with objective records based measures of technical quality of care: cross sectional study. BMJ 333(7557):19-22

Raposo M, Alves H, Duarte P (2009) Dimensions of service quality and satisfaction in healthcare: a patient's satisfaction index. Serv Bus 3(1):85-100

Ravald A, Grönroos C (1996) The value concept and relationship marketing. Eur J Mark 30(2):19-30

Reichheld F, Sasser WJ (1990) Zero defections: quality comes to services. Harvard Bus Rev 68(5):105-111

Reynolds KE, Beatty SE (1999) Customer benefits and company consequences of customer-salesperson relationships in retailing. J Retail 75(1):11-32

Rhee KJ, Bird J (1996) Perceptions and satisfaction with emergency department care. J Emerg Med 14(6):679-683

Robinson KA, Dickersin K (2002) Development of a highly sensitive search strategy for the retrieval of reports of controlled trials using PubMed. Int J Epidemiol 31(1):150-153

Rocha LRM, Veiga DF, e Oliveira P, Song EH, Ferreira LM (2013) Health service quality scale: Brazilian Portuguese translation, reliability and validity. BMC Health Serv Res 13(1):24-29

Rothman AA, Park H, Hays RD, Edwards C, Dudley RA (2008) Can additional patient experience items improve the reliability of and add new domains to the CAHPS ${ }^{\circledR}$ hospital survey? Health Serv Res 43(6):2201-2222

Samuels LB, Coffinberger RL, McCrohan KF (1983) Legislative responses to the plight of new car purchasers: a missed marketing opportunity. J Public Policy Mark 5:61-71

Seth N, Deshmukh S, Vrat P (2005) Service quality models: a review. Int J Qual Reliab Manag 22(9):913-949

Shostack GL (1977) Breaking free from product marketing. J Mark 41(2):73-80

Shostack GL (1985) Planning the service encounter. In: Czepiel JA, Solomon MR, Surprenant CF, Gutman EG (eds) The service encounter, vol 2. Lexington Books, Lexington, pp 243-254 
Sitzia J, Wood N (1997) Patient satisfaction: a review of issues and concepts. Soc Sci Med 45(12):1829-1843

Sivakumar K, Li M, Dong B (2014) Service quality: the impact of frequency, timing, proximity, and sequence of failures and delights. J Mark 78(1):41-58

Solomon MR, Surprenant C, Czepiel JA, Gutman EG (1985) A role theory perspective on dyadic interactions: the service encounter. J Mark 49(1):99-111

Soteriou AC, Stavrinides Y (2000) An internal customer service quality data envelopment analysis model for bank branches. Int J Bank Mark 18(5):246-252

Spreng RA, Mackoy RD (1996) An empirical examination of a model of perceived service quality and satisfaction. J Retail 72(2):201-214

Stryja C, Fromm H, Ried S, Jochem P, Fichtner W (2015) On the necessity and nature of E-mobility services-towards a service description framework. In: Nóvoa H, Drăgoicea M (eds) Exploring services science, vol 201. Lecture notes in business information processing. Springer, New York, pp 109-122. doi:10.1007/978-3-319-14980-6_9

Sun BC, Adams J, Orav EJ, Rucker DW, Brennan TA, Burstin HR (2000) Determinants of patient satisfaction and willingness to return with emergency care. Ann Emerg Med 35(5):426-434

Sun BC, Adams JG, Burstin HR (2001) Validating a model of patient satisfaction with emergency care. Ann Emerg Med 38(5):527-532

Surprenant CF, Solomon MR (1987) Predictability and personalization in the service encounter. J Mark 51(2):86-96

Sweeney JC, Soutar GN, Johnson LW (1997) Retail service quality and perceived value: a comparison of two models. J Retail Consumer Serv 4(1):39-48

Teas RK (1993) Expectations, performance evaluation, and consumers' perceptions of quality. J Mark 57(4):18-34

Thompson DA, Yarnold PR, Williams DR, Adams SL (1996) Effects of actual waiting time, perceived waiting time, information delivery, and expressive quality on patient satisfaction in the emergency department. Ann Emerg Med 28(6):657-665

Trout A, Magnusson AR, Hedges JR (2000) Patient satisfaction investigations and the emergency department: what does the literature say? Acad Emerg Med 7(6):695-709

Tukker A (2004) Eight types of product-service system: eight ways to sustainability? Experiences from SusProNet. Bus Strategy Environ 13(4):246-260

van Dun Z, Bloemer J, Henseler J (2010) Perceived customer contact centre quality: conceptual foundation and scale development. Serv Ind J 31(8):1347-1363

Venn S, Fone DL (2005) Assessing the influence of socio-demographic factors and health status on expression of satisfaction with GP services. Clin Gov Int J 10(2):118-125

Verhoef PC (2003) Understanding the effect of customer relationship management efforts on customer retention and customer share development. J Mark 67(4):30-45

Verhoef PC, Spring PN, Hoekstra JC, Leeflang PSH (2003) The commercial use of segmentation and predictive modeling techniques for database marketing in the Netherlands. Decis Support Syst 34(4):471-481

Walker MS, Ristvedt SL, Haughey BH (2003) Patient care in multidisciplinary cancer clinics: does attention to psychosocial needs predict patient satisfaction? Psychooncology 12(3):291-300

Walter N, Cleff T, Chu G (2013) Brand experience's influence on customer satisfaction and loyalty: a mirage in marketing research. Int J Manag Res Bus Strateg 2(1):130-144

Wei Z, Yonggui W, Yiren D, Zhong Y (2005) Customer relationship activities, relationship quality and relationship benefits: An empirical study in perspective of customers. In: International conference on services systems and services management, 13-15 June, pp 126-132

Westbrook RA, Day R, Hunt H (1982) Consumer satisfaction and the phenomenology of emotions during automobile owner-ship experiences. In: Day RL, Hunt K (eds) International fare in consumer satisfaction and complaining behavior: papers from the seventh annual conference on consumer satisfaction, dissatisfaction, and complaining behavior. Department of Marketing, School of Business, Indiana University Bloomington, Knoxville, pp 2-9

Wynstra F, Axelsson B, van der Valk W (2006) An application-based classification to understand buyersupplier interaction in business services. Int J Serv Ind Manag 17(5):474-496

Xu Y, Goedegebuure R, Van der Heijden B (2007) Customer perception, customer satisfaction, and customer loyalty within Chinese securities business: towards a mediation model for predicting customer behavior. J Relat Mark 5(4):79-104 
Yagil D (2002) The relationship of customer satisfaction and service workers' perceived control: examination of three models. Int J Serv Ind Manag 13(4):382-398

Yarnold PR, Michelson EA, Thompson DA, Adams SL (1998) Predicting patient satisfaction: a study of two emergency departments. J Behav Med 21(6):545-563

Yarris LM, Fu R, Frakes B, Magaret N, Adams AL, Brooks H, Norton RL (2012) How accurately can emergency department providers estimate patient satisfaction? West J Emerg Med 13(4):351-357

Yieh K, Chiao Y-C, Chiu Y-K (2007) Understanding the antecedents to customer loyalty by applying structural equation modeling. Total Qual Manag Bus Excell 18(3):267-284

Yu C-MJ, Wu L-Y, Y-c Chiao, Tai H-S (2005) Perceived quality, customer satisfaction, and customer loyalty: the case of Lexus in Taiwan. Total Qual Manag Bus Excell 16(6):707-719

Zeithaml VA (1988) Consumer perceptions of price, quality, and value: a means-end model and synthesis of evidence. J Mark 52(3):2-22

Zeithaml VA (2000) Service quality, profitability, and the economic worth of customers: what we know and what we need to learn. J Acad Mark Sci 28(1):67-85 